\title{
Heterogeneity in the relationship between biking and the built environment
}

Deborah Salon

Arizona State University

deborah.salon@asu.edu

Kailai Wang

The Ohio State University

wang.7684@buckeyemail.osu.edu

\author{
Matthew Wigginton Conway \\ Arizona State University \\ mwconway@asu.edu
}

Nathaniel Roth

nathanielroth@gmail.com

\begin{abstract}
Bicycling is an environmentally friendly, healthy, and affordable mode of transportation that is viable for short-distance trips. Urban planners, public health advocates, and others are therefore looking for strategies to promote more bicycling, including improvements to the built environment that make bicycling more attractive. This study presents an analysis of how key built environment characteristics relate to bicycling frequency based on a large sample from the 2012 California Household Travel Survey (California Department of Transportation, 2012) and detailed built environment data. The built environment characteristics we explore include residential and intersection density at anchor locations (home, work, school), green space, job access, landuse mix, and bicycle infrastructure availability. Analyses are conducted separately for three distinct demographic groups: school-age children, employed adults, and adults who are not employed. The key conclusion from this work is that the relationship between bicycling and some built environment characteristics varies between types of people - most dramatically between adults and children. To develop targeted policies with scarce resources, local policymakers need specific guidance as to which investments and policy changes will be most effective for creating "bikeable" neighborhoods. Our work indicates that the answer depends — at least in part — on who these bikeable neighborhoods are meant to serve.
\end{abstract}

\section{Article history:}

Received: December 23, 2017

Received in revised form:

September 23, 2018

Accepted: November 6, 2018

Available online: January 28, 2019

\section{$1 \quad$ Introduction}

Bicycling offers a wide range of benefits to both individuals and society. Cycling is an environmentally friendly and affordable mode of transportation that is viable for short distance trips. Using bicycles instead of cars reduces fuel consumption and associated harmful emissions, provides exercise for the cyclists, and can improve quality of life overall. For these reasons, urban planners, public health advocates, and others are looking for strategies to promote more bicycling, including improvements to the built environment that make bicycling more attractive. An understanding of the relationship between the

Copyright 2019 Deborah Salon, Matthew Wigginton Conway, Kailai Wang \& Nathaniel Roth http://dx.doi.org/10.5198/jtlu.2019.1350

ISSN: 1938-7849 | Licensed under the Creative Commons Attribution - Noncommercial License 4.0

The Journal of Transport and Land Use is the official journal of the World Society for Transport and Land Use (WSTLUR) and is published and sponsored by the University of Minnesota Center for Transportation Studies. 
built environment and individual decisions to bicycle provides an important basis for the development of such strategies. There are numerous studies in the current literature that focus on understanding the link between the built environment and bicycling from the perspectives of both health and transport (e.g., Pikora, Giles-Corti, Bull, Jamrozik, \& Donovan, 2003; Handy, Boarnet, Ewing, \& Killingsworth, 2002).

The present study adds to this existing literature by focusing on the heterogeneity in the association between built environment characteristics and bicycling behavior. A comparison of prior studies indicates that associations between bicycling and built environment characteristics are not always consistent. Because each study's sample, measure of the built environment, and estimation method was different, however, it is unclear whether the inconsistency in prior findings was due to different samples, measures, and methods, or due to heterogeneity in the underlying relationships. We use a single large survey together with measures of built environment characteristics and consistent statistical methods to estimate the association between bicycling frequency and built environment characteristics for different subpopulations. Specifically, we explore these relationships separately for three distinct demographic groups: school-age children, employed adults, and adults who are not employed. We also evaluate heterogeneity by gender among adults and by age among children.

Our findings indicate that substantial heterogeneity exists in the relationship between bicycling and built environment characteristics, especially between adults and children, between men and women, and between different ages of children. Most dramatically, we find that certain key characteristics have opposite effects on bicycling for different groups. For instance, overall density is positively associated with bicycling for high school children, but negatively associated with bicycling for elementary and middle school children. In addition, we find a strong positive relationship between a more connected street network and bicycling for older children and women. This characteristic is not statistically significant for men, and has a negative association with bicycling for elementary school children.

These findings suggest that women and children are more risk-averse and distance-sensitive than men when it comes to bicycling. Thus, our work adds quantitative evidence that supports policies and infrastructure that create "8 80 cities," suitable for bicycling by both 8 -year-olds and 80 -year-olds. The two main tenets are: create bicycle networks that connect residential areas with destinations, and make them safe and comfortable to use. This strategy may help encourage children - many of whom already bike in their neighborhoods - to begin bicycling for transportation as they get older, and to continue bicycling into adulthood.

\section{$2 \quad$ Literature review}

Of the large number of studies that we reviewed, only a handful investigated heterogeneity in the relationship between the built environment and bicycling. Tables 1 and 2 summarize original research papers that estimated the association between bicycling and the built environment. Table 1 summarizes studies focusing specifically on children, while Table 2 summarizes studies focusing on adults or the general population. Included are papers containing built environment covariates in a multivariate statistical framework. Some prior studies included multiple variables in some of the built environment characteristic categories in Tables 1 and 2; our tables provide multiple listings for these if they were not consistently significant with the same sign. Following Pucher, Dill and Handy (2010) and Willis, Manaugh and El-Geneidy (2015), we do not include studies that group bicycling and walking together as a single "active travel" mode. 


\subsection{Density}

Where residential density related variables were included in analyses, they were statistically significant approximately half of the time. Most studies indicated a positive relationship. This is expected, as denser suburban and urban environments generally have more destinations within easy biking distance. Most prior studies that found a negative relationship specifically involved children; Larsen et al. (2009) suggest that this finding is due to heavier traffic in denser areas, which can be a deterrent to cycling. Children - or perhaps more accurately parents - may be particularly sensitive to these safety concerns. Moran, Plaut, and Baron-Epel (2016) suggest that their negative finding is caused by a nonlinear relationship between density and cycling; they posit that their study area only contains densities high enough that the deterrent effects of density are more relevant than the additional accessibility provided.

Only one study of adults found a negative relationship. Conrow's (2018) negative association was found for users of the Strava mobile fitness app. The users of this app are likely primarily riding for recreation and exercise; they may be more motivated by country roads and paths, and less motivated by activity destinations.

\section{$2.2 \quad$ Diversity}

Land use diversity was statistically significant approximately a quarter of the time it was included in the reviewed prior studies. When statistically significant, the estimated relationship was positive, indicating that in neighborhoods with greater land use diversity, bicycling is more likely. Titze, Stronegger, Janschitz, and Oja (2008) suggested that the presence of shops and other services in one's home neighborhood encourages bicycling.

\subsection{Connectivity}

Where measures that indicate the connectivity of the street network were included in analyses, about a third of the estimated relationships with bicycling were statistically significant, and all were positive. Better connected streets allow for both shorter paths and more route choices between origins and destinations, reducing trip lengths and possibly also providing routes with less vehicle traffic.

\subsection{Bicycle infrastructure}

Bicycle-specific infrastructure such as bike lanes or paths, and bike-friendly infrastructure such as paved roadway shoulders were found to be statistically significant and positively associated with bicycling in approximately half of the analyses where they were included. This positive relationship is expected, since infrastructure specific for cycling is likely to encourage the activity. In fact, it is surprising that bicycle infrastructure is often found to be not significantly associated with bicycling. This may be simply because the presence of bicycle infrastructure is correlated with multiple other modeled factors that also encourage bicycling.

Alternatively, the presence of bicycle infrastructure may not reflect the presence of a functioning bicycling network. Indeed, a number of non-regression-based studies do suggest that a network of bicycling infrastructure is strongly correlated with bicycling activity. For example, Pucher and Buehler (2008) compared infrastructure and public policy in several European countries with the US. They illustrate that pro-bike and anti-car policies and infrastructure are much more common in European countries where there are also much higher cycling rates. Furth's (2012) review comes to a similar conclusion. Buehler and Handy (2008) detail the historical development of the extensive bicycle infrastructure in Davis, California. They observe that this infrastructure was at least partially responsible for cycling levels and a cycling culture they describe as similar to that of Amsterdam. 
The only study that found a negative relationship between bicycle infrastructure and cycling, Ma and Dill (2015), included both perceived and objectively measured infrastructure variables in their model. They found that the perception of off-street paths was negatively associated with cycling, after controlling for the objective presence of off-street paths.

\subsection{Green space}

The presence of green space or parks was found to have a statistically significant relationship with bicycling only one quarter of the time that it was included in analyses. In those cases, the relationship was positive, indicating that more green space is associated with more bicycling.

\subsection{Destination accessibility}

When statistically significant, prior estimates of the relationship between destination accessibility and bicycling were generally positive, suggesting that the availability of destinations — such as jobs or retailencourages cycling, most likely for transportation. Notably, no studies of children found this variable to be significant, suggesting that children may be cycling for recreation rather than to reach particular destinations.

Two studies found destination accessibility to have a significant negative effect. Moudon et al. (2005) suggest that the destination accessibility measure they use - convenience store square footage in the area - likely represents the presence of gas stations and high-speed arterials. Ma and Dill (2015) suggest that their negative finding may be due to competition with walking.

\subsection{Heterogeneity}

Though most studies reviewed in Tables 1 and 2 do not investigate heterogeneity directly, some do focus on particular demographic groups. This allows heterogeneity to be examined in a limited way, and we have pointed out differences in findings across demographic groups in the discussions above. These studies use different datasets, methods, and measures of built environment, however. This makes it difficult to deduce whether a difference in effects across groups is due to an actual difference in the underlying relationship, or simply a difference in study design (as was also encountered by Wong, Faulkner, \& Buliung 2011).

One study, while not looking at heterogeneity directly, did observe that results from their population diverged from results of studies of other populations in similar contexts. Van Dyck, Deforche, Cardon, and De Bourdeaudhuij (2009a) found that adolescents in a small town center in Belgium cycled less than their counterparts in a nearby suburban area. This finding diverged from a similar study of adults (Van Dyck, Cardon, Deforche, \& De Bourdeaudhuij, 2009b), leading the authors to conclude that the built environment may have differential effects on the two groups. Our research examines this possibility explicitly in the context of California, and our findings are consistent with these observations.

One type of heterogeneity that has been explored is the extent to which built environment factors may relate to the gender divide in cycling (Garrard, Handy, \& Dill, 2012, provide an overview). Trapp et al. (2011) found most neighborhood built environment factors to be significant predictors of boys' cycling to school, but not girls' cycling, although the opposite effect was observed for the presence of busy road crossings. Mitra and Nash (2018) examined whether relationships between cycling and the built environment differed among male and female university students, and found that women were more sensitive to some built environment characteristics, such as the presence of high-speed roads, than men. Our study contributes by examining heterogeneity across a broader range of dimensions, including age and employment status as well as gender. 
Table 1. Built environment relationships with cycling, children

\begin{tabular}{|c|c|c|c|}
\hline $\begin{array}{l}\text { Built Environment } \\
\text { Characteristic }\end{array}$ & Finding & Studies & $\mathrm{N}$ \\
\hline \multirow[t]{3}{*}{ Local density } & + & & 0 \\
\hline & NS & $\begin{array}{l}\text { Ewing, Schroeer, \& Greene, } 2004 \text { (NA); de Meester et al., } 2012 \text { (EU) }{ }^{1} \text {; } \\
\text { Carlson et al., } 2015 \text { (NA) }\end{array}$ & 3 \\
\hline & - & Ducheyne et al., 2013 (EU); Moran et al., 2016 (ME) & 2 \\
\hline \multirow[t]{3}{*}{ Land-use mix } & + & & 0 \\
\hline & NS & Ewing et al., 2004 (NA); de Meester et al., 2012 (EU) ${ }^{1}$ & 2 \\
\hline & - & & 0 \\
\hline \multirow[t]{3}{*}{ Street network connectivity } & + & Carlson et al., 2015 (NA) & 1 \\
\hline & NS & $\begin{array}{l}\text { Ewing et al., } 2004 \text { (NA); Trapp et al., } 2011 \text { (OC); de Meester et al., } 2012 \\
(\mathrm{EU})^{1} \text {; Ducheyne, De Bourdeaudhuij, Lenoir, Spittaels, \& Cardon, } 2013 \\
(\mathrm{EU})^{2} \text {; Moran et al., } 2016 \text { (ME) }\end{array}$ & 5 \\
\hline & - & & 0 \\
\hline \multirow[t]{3}{*}{ Bike infrastructure } & + & Fitch, Thigpen, \& Handy, $2016(\mathrm{NA})^{3}$ & 1 \\
\hline & NS & $\begin{array}{l}\text { Ewing et al., } 2004 \text { (NA); Ducheyne et al., } 2013 \text { (EU); Fitch et al., } 2016 \\
\text { (NA) }\end{array}$ & 3 \\
\hline & - & & 0 \\
\hline \multirow[t]{3}{*}{ Green space } & + & & 0 \\
\hline & NS & Moran et al., 2016 (ME) & 1 \\
\hline & - & & 0 \\
\hline \multirow[t]{3}{*}{ Destination accessibility } & + & & 0 \\
\hline & NS & $\begin{array}{l}\text { Ewing et al., } 2004 \text { (NA); Ducheyne et al., } 2013 \text { (EU); Carlson et al., } \\
2015 \text { (NA); Moran et al., } 2016 \text { (ME) }\end{array}$ & 4 \\
\hline & - & & 0 \\
\hline \multicolumn{4}{|c|}{$\begin{array}{l}{ }^{1} \text { This study combined density, land-use mix, and street network connectivity into one "walkability" index. } \\
{ }^{2} \text { This variable was part of an index that included access to stores as well as access to transit and neighborhood hilliness } \\
\text { (Rosenberg et al., 2009). }\end{array}$} \\
\hline \multicolumn{4}{|c|}{$\begin{array}{l}{ }^{3} \text { The included variables related to "low stress" bike routes, which include infrastructure as well as quiet neighborhood } \\
\text { streets. }\end{array}$} \\
\hline
\end{tabular}


Table 2. Built environment relationships with cycling, adults/general population

\begin{tabular}{|c|c|c|c|}
\hline $\begin{array}{l}\text { Built } \\
\text { Environment } \\
\text { Characteristic }\end{array}$ & Finding & Studies & $\mathrm{N}$ \\
\hline \multirow[t]{3}{*}{ Local density } & + & $\begin{array}{l}\text { Parkin, Wardman, \& Page., } 2007 \text { (EU); Winters, Brauer, Setton, \& Teschke, } 2010 \\
\text { (NA); Beenackers et al., } 2012 \text { (OC); Cui, Mishra, \& Welch, } 2014 \text { (US) }\end{array}$ & 4 \\
\hline & NS & $\begin{array}{l}\text { Cervero, Sarmiento, Jacoby, Gomez, \& Neimen, } 2009 \text { (SA); Winters et al., } 2010 \text { (NA); } \\
\text { Beenackers et al., } 2012 \text { (OC); Zhao, } 2014 \text { (AS); Conrow, } 2018 \text { (OC); Mitra \& Nash, } \\
2018 \text { (NA) }\end{array}$ & 6 \\
\hline & - & Conrow, 2018 (OC) & 1 \\
\hline \multirow[t]{3}{*}{ Land-use mix } & + & Winters et al., 2010 (NA); Zhao, 2014 (AS); & 2 \\
\hline & NS & $\begin{array}{l}\text { Cervero \& Duncan, } 2003 \text { (NA); Titze et al., } 2008 \text { (EU); Winters et al., } 2010 \text { (NA); } \\
\text { Cervero et al., } 2009 \text { (SA); Beenackers et al., } 2012 \text { (OC) }\end{array}$ & 5 \\
\hline & - & & 0 \\
\hline \multirow[t]{3}{*}{$\begin{array}{l}\text { Street network } \\
\text { connectivity }\end{array}$} & + & $\begin{array}{l}\text { Frank, Bradley, Kavage, Chapman, \& Lawton, } 2008 \text { (NA); Cervero et al., } 2009 \text { (SA); } \\
\text { Winters et al., } 2010 \text { (NA); Beenackers et al., } 2012 \text { (OC); Conrow, } 2018 \text { (NA) }\end{array}$ & 5 \\
\hline & NS & $\begin{array}{l}\text { Cervero \& Duncan, } 2003 \text { (NA); Frank et al., } 2008 \text { (NA); Cervero et al., } 2009 \text { (SA); } \\
\text { Beenackers et al., } 2012 \text { (OC); Zhao, } 2014 \text { (AS); Conrow, } 2018 \text { (NA) }\end{array}$ & 6 \\
\hline & - & & 0 \\
\hline \multirow[t]{3}{*}{$\begin{array}{l}\text { Bike } \\
\text { infrastructure }\end{array}$} & + & $\begin{array}{l}\text { Dill \& Carr, } 2003 \text { (NA); Moudon et al., } 2005 \text { (NA); Krizek \& Johnson, } 2006 \text { (NA); } \\
\text { Parkin et al., } 2007 \text { (EU); Titze et al., } 2008 \text { (EU); Handy, Xing, \& Buehler, } 2010 \text { (NA); } \\
\text { Winters et al., } 2010 \text { (NA); Zhao, } 2014 \text { (AS); Ma \& Dill, } 2015 \text { (US); Conrow, } 2018 \\
\text { (OC); Mitra \& Nash, } 2018 \text { (NA) }\end{array}$ & 11 \\
\hline & NS & $\begin{array}{l}\text { Moudon et al., } 2005 \text { (NA); Krizek \& Johnson, } 2006 \text { (NA); Cervero et al., } 2009 \text { (SA); } \\
\text { Handy, Xing, \& T. Buehler, } 2010 \text { (NA); Winters et al., } 2010 \text { (NA); Beenackers et al., } \\
2012 \text { (OC); Ma \& Dill, } 2015 \text { (US); Conrow, } 2018 \text { (OC); Mitra \& Nash, } 2018 \text { (NA) }\end{array}$ & 9 \\
\hline & - & Ma \& Dill, 2015 (US); & 1 \\
\hline \multirow[t]{3}{*}{ Green space } & + & Wendel-Vos et al., 2004 (EU); Beenackers et al., 2012 (OC); & 2 \\
\hline & NS & $\begin{array}{l}\text { Wendel-Vos et al., } 2004 \text { (EU); Cervero et al., } 2009 \text { (SA); Winters et al., } 2010 \text { (NA); } \\
\text { Beenackers et al., } 2012 \text { (OC); Moudon et al., } 2005 \text { (NA) }\end{array}$ & 5 \\
\hline & - & & 0 \\
\hline \multirow[t]{3}{*}{$\begin{array}{l}\text { Destination } \\
\text { accessibility }\end{array}$} & + & $\begin{array}{l}\text { Moudon et al., } 2005 \text { (NA); Zhao, } 2014 \text { (AS); Cui et al., } 2014 \text { (US); Ma \& Dill, } 2015 \\
\text { (US); Mitra \& Nash, } 2018 \text { (NA) }\end{array}$ & 5 \\
\hline & NS & $\begin{array}{l}\text { Cervero \& Duncan, } 2003 \text { (NA); Moudon et al., } 2005 \text { (NA); Cervero et al., } 2009 \text { (SA); } \\
\text { Beenackers et al., } 2012 \text { (OC); Zhao, } 2014 \text { (AS); Cui et al., } 2014 \text { (US); Ma \& Dill, } 2015 \\
\text { (US); Mitra \& Nash, } 2018 \text { (NA) }\end{array}$ & 8 \\
\hline & - & Moudon et al., 2005 (NA); Ma \& Dill, 2015 (US) & 2 \\
\hline
\end{tabular}

\section{Data}

The individual-level bicycling data for this project come from the 2012 California Household Travel Survey (CHTS). The CHTS sampled households throughout California, collecting household and individual demographic data, information about habitual commute trips, and a 24-hour travel diary. The initial survey included three questions related to bicycling: 
1. How many bicycles in working condition are available to people in your household?

2. In the past week, how many times did you/this person ride a bicycle outside including bicycling for exercise?

3. How do/does you/this person normally get to this primary job/school?

Bicycle trips were also reported in the travel diary, but because such a small percentage of respondents bicycled on the travel diary day, results based on those data are not presented here.

We used the first of these questions to restrict our sample to the two-thirds of CHTS respondents living in households with at least one working bicycle, and used the second question's responses as our outcome variable. Using a 7-day trip count rather than a 24-hour travel diary is an advantage when studying an activity such as bicycling, which may be infrequent. Answers to the third question helped us interpret the results. The sample used for this analysis includes 45,027 individuals in 18,007 households.

To investigate the link between bicycling and built environment characteristics, we paired the CHTS data with land use and census-based data. Theory as well as prior studies guided our choice of built environment characteristics to include (see Table 3). Short trip lengths allow travelers the flexibility to bicycle. Dense and mixed-use development can shorten trip lengths by bringing homes close to jobs, schools, and other key destinations. Built environment features that lengthen trips can discourage bicycling, such as lack of street connectivity or large tracts of undeveloped land. In busy areas, safetyenhancing infrastructure such as bike lanes or paths is also critical. Table 4 provides summary statistics (mean, standard deviation, and range) for both built environment and demographic control variables included in the regression models.

Using geocoded locations of home, work, and school, we identified characteristics of the built environment for these key anchor locations for each CHTS respondent in our sample. Built environment information was derived from three sources: the 2012 Urban Footprint base variables, the American Community Survey (U.S. Census Bureau, 2014), and the Longitudinal Employer-Household Dynamics (LEHD) data (U.S. Census Bureau, 2010). The Urban Footprint variables include land cover, parcel, census, and transportation network information measured at the resolution of a 150-meter grid. The geographic extent of our analysis was determined by the extent of the Urban Footprint data, available for the San Francisco Bay Area, the Sacramento metropolitan area, the San Joaquin Valley, the Los Angeles metropolitan area, and San Diego County. This represents all major urban and suburban areas in California. 
Table 3. Measurement of built environment

\begin{tabular}{|c|c|c|}
\hline Built Environment & Indicators & Measurements \\
\hline \multirow[t]{2}{*}{ Local density } & $\begin{array}{l}\text { Central Business District (Salon, } \\
\text { 2016) }\end{array}$ & $\begin{array}{l}\text { A binary indicator of whether the home location is in a Cen- } \\
\text { tral Business District census tract }\end{array}$ \\
\hline & Residential density (UF) & $\begin{array}{l}\text { Residents per square meter within one mile of home, work, } \\
\text { and school locations }\end{array}$ \\
\hline $\begin{array}{l}\text { Diversity of land } \\
\text { use }\end{array}$ & $\begin{array}{l}\text { Entropy-based residential-employ- } \\
\text { ment mix (UF) }\end{array}$ & $\begin{array}{l}\text { Indicator of the residential-employment mix of developed } \\
\text { acres within } 1 \text { mile of the home location. }\end{array}$ \\
\hline Road connectivity & Number of intersections (UF) & $\begin{array}{l}\text { The number of non-highway intersections of three or more } \\
\text { streets within one mile of home, work, and school locations. }\end{array}$ \\
\hline \multirow[t]{2}{*}{ Bike lanes } & Bike route length $(\mathrm{UF})$ & $\begin{array}{l}\text { The sum meters of bike routes within one mile of home loca- } \\
\text { tion }\end{array}$ \\
\hline & $\begin{array}{l}\text { Bike routes in } 75 \text { th percentile at } \\
\text { both home and work/school (UF) }\end{array}$ & $\begin{array}{l}\text { A binary indicator of whether both home and workplace/ } \\
\text { school locations have bike route lengths that are above the } \\
\text { 75th percentile in bike infrastructure availability for our } \\
\text { sample }\end{array}$ \\
\hline Green space & Park area (UF) & Park area within one mile of home location \\
\hline \multirow[t]{2}{*}{ Job access } & Local job access (LEHD) & $\begin{array}{l}\text { Distance-weighted employment within } 5 \text { miles of home } \\
\text { census tract }\end{array}$ \\
\hline & Regional job access (LEHD) & $\begin{array}{l}\text { Distance-weighted employment between } 5 \text { and } 50 \text { miles of } \\
\text { home census tract }\end{array}$ \\
\hline $\begin{array}{l}\text { Bike-friendly } \\
\text { Environment }\end{array}$ & $\begin{array}{l}\text { Non-motorized commuting } \\
\text { (ACS) }\end{array}$ & Percent non-motorized commuters in home census tract \\
\hline
\end{tabular}

UF = Urban Footprint; LEHD = Longitudinal Employer Household Dynamics; ACS = American Community Survey (U.S. Census Bureau, 2010, 2014)

Built environment characteristics from the Urban Footprint dataset are measured within 1-mile buffers of each respondent's home and, where applicable, work or school locations. These variables capture the land use surrounding where survey respondents are actually located, rather than summarizing census tract-level information. In addition, an indicator for Central Business District census tracts was developed as part of a neighborhood typology analysis (Salon, 2016). Local and regional job access measures were calculated as distance-weighted sums of employment estimates (LEHD) at the census block group level. To capture additional aspects of built environment bicycle friendliness, we also include the percent of commuters reporting non-motorized modes in the home census tract.

A limitation of these data is that we do not know if the reported bicycling trips began at home; some people drive with their bicycles to areas with desirable built environment characteristics for recreational bicycle trips. This means that our built environment measures at home, work, and school locations do not necessarily capture the built environment that was actually relevant for the bicycling trips taken - though we expect that they are relevant for a substantial fraction of those trips. Salon (2016) calculates that $87 \%$ of California bike trips reported in the 2009 National Household Travel Survey begin or end at home.

The main contribution of this paper is to highlight how the relationships between bicycling and the built environment vary according to demographic characteristics of the cyclists. As a precursor to this, the box-and-whiskers diagram in Figure 1 graphically displays the large differences in bicycling fre- 
quency between different ages of school children, employed adults, and not-employed adults by gender. The boxes represent the 25th and 75th percentiles of the distribution of weekly bicycling trips for each demographic category, with the median indicated by a horizontal boldface line. It is evident from this figure that children bicycle more than adults, and that males bicycle more than females in each category. It is particularly striking that more than $75 \%$ of women did not ride a bicycle at all in the one week reporting period. We estimate separate models for each demographic group, and where relevant we include interaction terms to estimate separate relationships between built environment characteristics and bicycling for males and females, and for different age categories of children.

Table 4. Sample descriptive statistics for variables included in regression models (not weighted)

\begin{tabular}{|c|c|c|c|c|c|c|}
\hline \multirow[b]{2}{*}{ Variable } & \multicolumn{2}{|c|}{ Children $(\mathrm{N}=10,820)$} & \multicolumn{2}{|c|}{ Employed Adults $(\mathrm{N}=21,014)$} & \multicolumn{2}{|c|}{$\begin{array}{l}\text { Not-Employed Adults } \\
(\mathrm{N}=13,193)\end{array}$} \\
\hline & Mean (SD) & Range & Mean (SD) & Range & Mean (SD) & Range \\
\hline Bike Trips in 7 Days & $1.98(3.33)$ & {$[0,50]$} & $0.8(2.2)$ & {$[0,50]$} & $0.72(2.14)$ & {$[0,50]$} \\
\hline $\begin{array}{l}\text { Population, 1-mile } \\
\text { radius }(\mathrm{H})\end{array}$ & $2291(1761)$ & {$[0,16859]$} & $2340(1852)$ & {$[0,16859]$} & $2230(1774)$ & $\begin{array}{l}{[0.1,} \\
16433]\end{array}$ \\
\hline $\begin{array}{l}\text { Population, 1-mile } \\
\text { radius (S/W) }\end{array}$ & $2287(1763)$ & {$[0,16173]$} & $2458(2498)$ & {$[0,17074]$} & N/A & \\
\hline $\begin{array}{l}\text { Intersections, 1-mile } \\
\text { radius }(\mathrm{H})\end{array}$ & $229(133)$ & {$[1,866]$} & $234(141)$ & {$[0,1000]$} & $228(139)$ & {$[0,936]$} \\
\hline $\begin{array}{l}\text { Intersections, 1-mile } \\
\text { radius (S/W) }\end{array}$ & $237(134)$ & {$[0,958]$} & $245(161)$ & {$[0,984]$} & N/A & \\
\hline $\begin{array}{l}\text { Bike Route } \mathrm{Km} \text {, } \\
\text { 1-mile radius }(\mathrm{H})\end{array}$ & $8.9(8.6)$ & {$[0,48.2]$} & $9.6(9)$ & {$[0,52.6]$} & $8.54(8.58)$ & {$[0,51.8]$} \\
\hline $\begin{array}{l}\% \text { Park Area, 1-mile } \\
\text { radius }(\mathrm{H})\end{array}$ & $6 \%(10 \%)$ & {$[0,93 \%]$} & $7 \%(10 \%)$ & {$[0,99 \%]$} & $6 \%(10 \%)$ & {$[0,99 \%]$} \\
\hline $\begin{array}{l}\% \text { Non-Motorized } \\
\text { Commuters in } \\
\text { Home Tract }\end{array}$ & $3 \%(4 \%)$ & {$[0,58 \%]$} & $3 \%(5 \%)$ & {$[0,66 \%]$} & $3 \%(4 \%)$ & {$[0,64 \%]$} \\
\hline $\begin{array}{l}\text { Land-Use Mix, } \\
\text { 1-mile radius }(\mathrm{H})\end{array}$ & $0.82(0.19)$ & {$[0,1]$} & $0.82(0.19)$ & {$[0,1]$} & $0.82(0.2)$ & {$[0,1]$} \\
\hline Local Job Access & N/A & & $5.43(6.29)$ & {$[0,69]$} & $4.89(5.7)$ & {$[0,64]$} \\
\hline Regional Job Access & N/A & & $15.15(11.16)$ & {$[0,42]$} & $14.2(11.62)$ & {$[0,42.35]$} \\
\hline HH Size & $4.54(1.2)$ & {$[2,8]$} & $3.3(1.41)$ & {$[1,8]$} & $3.35(1.53)$ & {$[1,8]$} \\
\hline Age (adult only) & N/A & & $46(12)$ & {$[18,87]$} & $52(19)$ & {$[18,99]$} \\
\hline Income (\$1000’s) & $101.81(74.45)$ & {$[5,300]$} & $113.77(70.86)$ & {$[5,300]$} & $82.56(64.49)$ & {$[5,300]$} \\
\hline $\begin{array}{l}\text { Distance to School/ } \\
\text { Work }\end{array}$ & $3.41(4.25)$ & {$[0.01,29.92]$} & $16.42(16.52)$ & {$[0,100]$} & N/A & \\
\hline Walk Trips in 7 Days & $5.49(5.59)$ & {$[0,50]$} & $4.53(4.98)$ & {$[0,50]$} & $5.14(5.89)$ & {$[0,50]$} \\
\hline Male & $52 \%$ & & $54 \%$ & & $41 \%$ & \\
\hline White & $68 \%$ & & $73 \%$ & & $71 \%$ & \\
\hline Driver's license & $6 \%$ & & $97 \%$ & & $83 \%$ & \\
\hline Transit pass holder & N/A & & $11 \%$ & & $9 \%$ & \\
\hline Bachelor Degree & N/A & & $55 \%$ & & $35 \%$ & \\
\hline
\end{tabular}




\begin{tabular}{|c|c|c|c|}
\hline $\begin{array}{l}\text { Scientist, Doctor, } \\
\text { Teacher }\end{array}$ & N/A & $22 \%$ & N/A \\
\hline Disabled & $2 \%$ & $2 \%$ & $15 \%$ \\
\hline Homeowner & $77 \%$ & $83 \%$ & $82 \%$ \\
\hline Apartment dweller & $9 \%$ & $10 \%$ & $9 \%$ \\
\hline $\begin{array}{l}\text { HH member uses } \\
\text { transit }\end{array}$ & $25 \%$ & $24 \%$ & $24 \%$ \\
\hline Children in $\mathrm{HH}$ & $100 \%$ & $46 \%$ & $37 \%$ \\
\hline Home in CBD & $1 \%$ & $2 \%$ & $1 \%$ \\
\hline $\begin{array}{l}\text { Bike route density } \\
\text { above } 75 \text { th percentile } \\
(\mathrm{H}) \text { and }(\mathrm{S} / \mathrm{W})\end{array}$ & $16 \%$ & $15 \%$ & N/A \\
\hline Zero Vehicle HH & $2 \%$ & $2 \%$ & $4 \%$ \\
\hline One Vehicle HH & $16 \%$ & $15 \%$ & $20 \%$ \\
\hline Two Vehicle HH & $56 \%$ & $49 \%$ & $46 \%$ \\
\hline Three+ Vehicle HH & $26 \%$ & $34 \%$ & $30 \%$ \\
\hline One bicycle $\mathrm{HH}$ & $14 \%$ & $25 \%$ & $33 \%$ \\
\hline Two bicycle HH & $23 \%$ & $32 \%$ & $34 \%$ \\
\hline Three+ bicycle HH & $64 \%$ & $42 \%$ & $33 \%$ \\
\hline Elementary Age & $43 \%$ & N/A & N/A \\
\hline Middle School Age & $24 \%$ & N/A & N/A \\
\hline High School Age & $33 \%$ & N/A & N/A \\
\hline
\end{tabular}

H: Home, S/W: School/Work, HH: Household

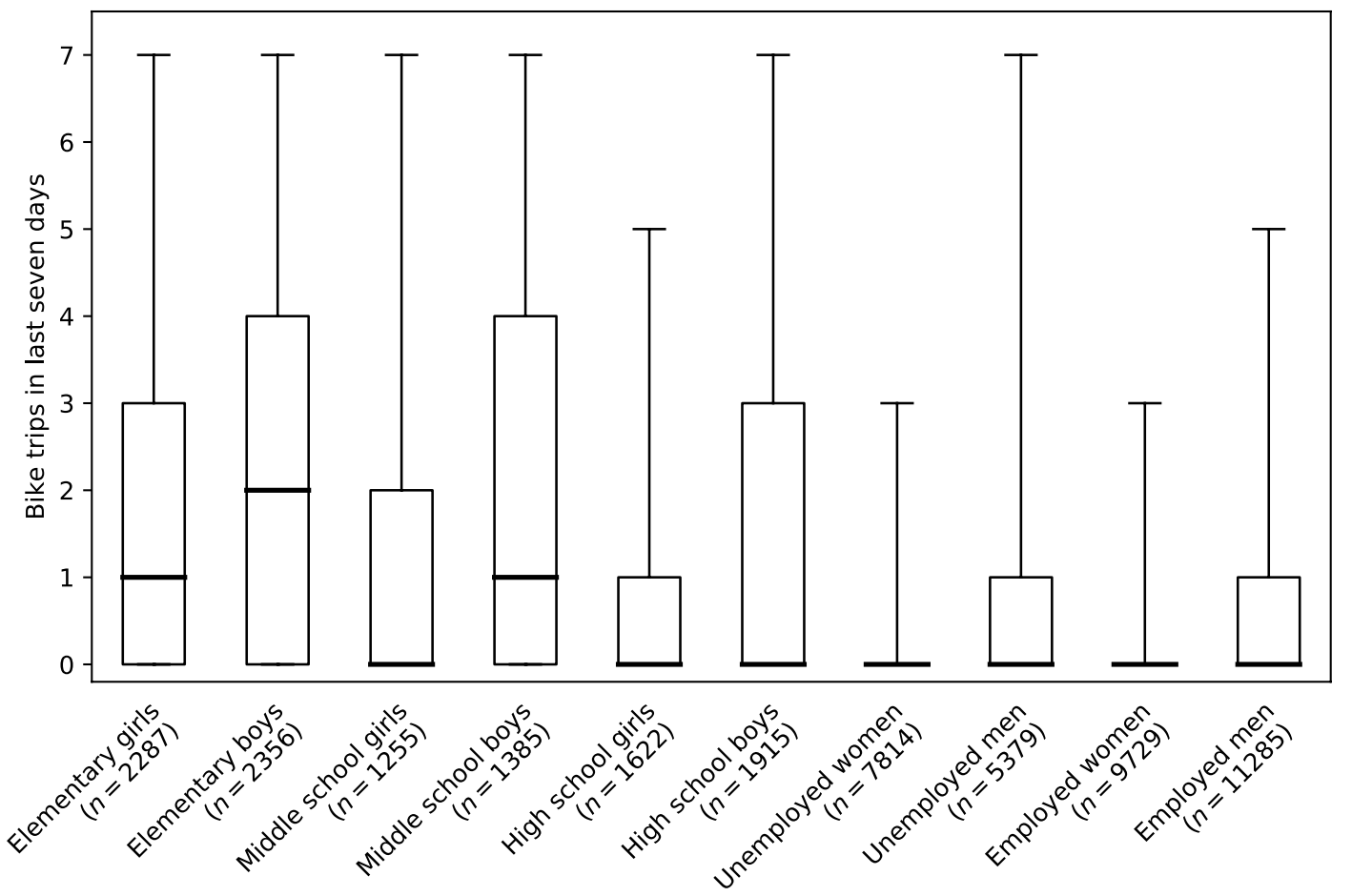

Figure 1. Average cicycling trips in one week by gender and subpopulation 


\section{$4 \quad$ Methods}

Since our outcome variable is the number of bike trips a person made in the last week, we opted to use a count model, which is suitable for modeling nonnegative integer outcomes. The most common type of count model is the Poisson model, which models the outcome process as a Poisson distribution. This model has a requirement that the mean of the data be equal to the variance. This requirement is relaxed by the negative binomial model, which adds an error term to account for unobserved heterogeneity and allow for variance greater than the mean (so-called overdispersion; Washington, Karlaftis, \& Mannering, 2011, Ch. 11). The Cameron and Trivedi test of overdispersion (described in Washington et al., 2011, pp. 293-4) indicate that our data are overdispersed, so we use the negative binomial model. ${ }^{1}$

The negative binomial model is a generalized linear model, wherein a linear combination of predictors is exponentiated to model the outcome variable (Equation 1).

$$
E(y)=e^{x \beta}
$$

where $y$ is bike trips in last week

$x$ is a vector of model covariates, and

$\beta$ is a vector of model estimated coefficients

The coefficients, therefore, are not linear marginal effects, but rather a difference in logarithms. In lieu of raw model coefficients, we report incident rate ratios (IRRs), which are more readily interpretable. Mathematically, the IRRs are simply the exponentiated raw coefficient estimates (Equation 2).

$$
\operatorname{IRR}\left(x_{j}\right)=e^{\beta_{j}}=\frac{E\left(y \mid x, x_{j}+1\right)}{E(y \mid x)}
$$

where $j$ indexes model covariates, and $x, y$, and $\beta$ are as specified under Equation 1

IRRs are equal to the ratio of the predicted rate (i.e., count) of bicycle trips when a covariate increases by one unit to the original predicted rate of bicycle trips. An IRR of 1 indicates that a variable has no effect on bicycling; increasing that variable by one unit does not change the predicted rate of bike trips. An IRR of 1.2 would indicate that a unit increase in the covariate is associated with a $20 \%$ increase in bicycle trips. IRR values below 1 indicate a negative association. Due to the particular functional form of this model, the IRRs are constant over the full range of the variable space.

Note that because IRRs imply a percent change in bicycling, IRRs of the same magnitude can indicate very different absolute effects, depending on the number of bicycle trips originally taken. This can prove confusing. For instance, children in this sample bicycle more than employed adults. The two groups have similar estimated IRRs for the relationship between walking trips in the past week and bicycling trips in the past week (1.07 vs 1.06), indicating that an additional walk trip is associated with a 6-7\% increase in weekly bicycle trips. The implied absolute effect size for these two groups, however, differs by more than a factor of 2 ( 0.14 vs 0.06$)$. Because both may be relevant, we report and discuss both IRRs and marginal effect results.

Weights for each individual are included in the CHTS dataset, and can be used to adjust results to be representative of the population of California. We used these weights to create the average number of bike trips by age, employment, and gender in Figure 1 and when calculating weighted average marginal effects. These marginal effects indicate the weighted average across this sample of the absolute change in the number of bicycle trips in 7 days associated with a one unit increase in each variable.

\footnotetext{
${ }^{1}$ We also tested zero-inflated model specifications, but found no differences in the results that change their meaning. While there are many zeroes in these data, we view these zeroes as simply a common outcome of the continuous decision of how much to bike for those in bicycle-owning households, rather than a decision made using different criteria about whether to bike at all. This reasoning led us to prefer the negative binomial specification.
} 
The model itself, however, is estimated using unweighted data. If the probability of sampling a particular individual is uncorrelated with the dependent variable (number of bike trips) conditioned on the covariates, weighting is unnecessary (Solon, Haider, \& Wooldridge, 2015). Because our model includes many of the CHTS weighting variables as covariates, we conclude that the relationships we care about should be properly estimated in an unweighted regression. For full transparency, the descriptive statistics in Table 4 are also unweighted.

We tested the models for multicollinearity. Interpreting variance inflation factors can be difficult when variables are included both in their base form and in interaction terms, as the interaction term is perforce somewhat correlated with the base variable. However, removing all interaction terms from our final model yields variance inflation factors for all variables below 4, with the exception of income (because it is correlated with income squared) and levels of car ownership (because one-car households cannot be two- or three-car households, and vice versa).

\subsection{Principal component analysis}

Population and intersection density within one mile of both home and work/school locations are important built environment characteristics. These variables are highly collinear, however, precluding including all of them in the model. To solve this problem, we used principal component analysis to identify three uncorrelated factors that explain most of the variation in these four density variables, and included these principal components as covariates in our models of bicycling frequency.

Table 5 presents the principal component loadings. The analysis was done separately for each model subsample (children, not-employed adults, and employed adults), but the interpretations are the same for each subsample.

Component 1 (General density) has positive loadings on all original density variables. Areas with high values for all density variables also have high values for this component.

Component 2 (Home vs work/school) has positive loadings for both population and intersection density measured at the home location, and negative loadings for densities measured near work/school. Thus, a respondent living in a higher density environment relative to their work/school will have a larger value for this component. Of course, there is no work/school location for not-employed adults, so this component is absent for that subsample.

Table 5. Principal component variable loadings

\begin{tabular}{|c|c|c|c|c|}
\hline & $\begin{array}{l}\text { Home } \\
\text { Intersection } \\
\text { Density }\end{array}$ & $\begin{array}{l}\text { Work /School } \\
\text { Intersection } \\
\text { Density }\end{array}$ & $\begin{array}{l}\text { Home Popula- } \\
\text { tion Density }\end{array}$ & $\begin{array}{l}\text { Work/School } \\
\text { Population } \\
\text { Density }\end{array}$ \\
\hline \multicolumn{5}{|l|}{ Employed Adults } \\
\hline Component 1: General density & 0.498 & 0.489 & 0.514 & 0.498 \\
\hline Component 2: Home vs. work/school & 0.514 & -0.515 & 0.472 & -0.497 \\
\hline Component 3: Intersection vs. pop. density & 0.397 & 0.595 & -0.391 & -0.579 \\
\hline \multicolumn{5}{|l|}{ Not-Employed Adults } \\
\hline Component 1: General density & 0.707 & N/A & 0.707 & N/A \\
\hline Component 2: Home vs. work/school & N/A & N/A & N/A & N/A \\
\hline Component 3: Intersection vs. pop. density & 0.707 & N/A & -0.707 & N/A \\
\hline \multicolumn{5}{|l|}{ Schoolchildren } \\
\hline Component 1: General density & 0.496 & 0.496 & 0.505 & 0.503 \\
\hline Component 2: Home vs. school & 0.544 & -0.517 & 0.453 & -0.482 \\
\hline Component 3: Intersection vs. pop. density & 0.483 & 0.525 & -0.502 & -0.489 \\
\hline
\end{tabular}

Notes: Input variables were standardized before applying principal component analysis, and the reported components were not rotated. 
Component 3 (Intersection vs. population density) has positive loadings for intersection density and negative loadings for population density. Respondents who have a larger value for this component live or work in areas with street networks that are particularly well connected, in comparison with areas of similar density.

We used GeoDa software to test for spatial autocorrelation in our model residuals, and found virtually none. The main statistical analysis was performed using Stata 15.1 for Mac, using the nbreg command and clustering errors by household.

\section{$5 \quad$ Results}

Tables 6 and 7 present our main model IRR estimation results and weighted average marginal effects, respectively. Each of these tables is divided into three sections - one for children, one for not-employed adults, and one for employed adults. In the children's model, the relationships between certain variables and bicycling are estimated and reported separately for elementary (age 5-10), middle (age 11-13), and high school (age 14-17) children. In the adult models, the relationships between certain variables and bicycling are estimated and reported separately for women and men. Many of the variables in these models are insignificant, but are retained in order to present comparisons between groups and prevent omitted variable bias. Removing these variables has almost no effect on the estimated coefficients of the remaining variables; the Appendix contains these alternate estimation tables.

The remainder of the Results section is divided into three parts. The first details our main results for the associations between the built environment and bicycling, the second summarizes our findings for the associations between demographic characteristics and bicycling, and the last presents limitations.

Table 6. Negative binomial regression IRR estimates of 7-day bicycling frequency

Note: $95 \%$ confidence intervals are given below point estimates. Asterisks designate statistical significance, where ${ }^{* * *}$ indicates $\mathrm{p}<0.01,{ }^{* *}$ indicates $\mathrm{p}<0.05,{ }^{*}$ indicates $\mathrm{p}<0.10$. Z-statistics are shown in italics.

\begin{tabular}{|c|c|c|c|c|c|c|c|}
\hline & \multicolumn{3}{|c|}{ Schoolchildren } & \multicolumn{2}{|c|}{ Not-Employed Adults } & \multicolumn{2}{|c|}{ Employed Adults } \\
\hline Variable & Elementary & Middle & High & Female & Male & Female & Male \\
\hline Constant & $\begin{array}{l}1.19 \\
(0.85,1.66) \\
0.99\end{array}$ & & & $\begin{array}{l}9.83^{* * *} \\
(4.37,22.12) \\
5.52\end{array}$ & & $\begin{array}{l}6.45^{* * *} \\
(3.32,12.52) \\
5.51\end{array}$ & \\
\hline General density ${ }^{a}$ & $\begin{array}{l}0.94^{* * *} \\
(0.91,0.96) \\
-4.83\end{array}$ & $\begin{array}{l}0.93^{* * *} \\
(0.89,0.97) \\
-3.56\end{array}$ & $\begin{array}{l}1.08^{* * *} \\
(1.03,1.13) \\
3.09\end{array}$ & $\begin{array}{l}1.02 \\
(0.94,1.10) \\
0.45\end{array}$ & $\begin{array}{l}1.07^{*} \\
(1.00,1.15) \\
1.86\end{array}$ & $\begin{array}{l}1.01 \\
(0.97,1.06) \\
0.49\end{array}$ & $\begin{array}{l}1.02 \\
(0.98,1.06) \\
1.04\end{array}$ \\
\hline $\begin{array}{l}\text { Home vs. work/ } \\
\text { school }^{a}\end{array}$ & $\begin{array}{l}1.01 \\
(0.94,1.10) \\
0.37\end{array}$ & $\begin{array}{l}1.05 \\
(0.95,1.16) \\
0.88\end{array}$ & $\begin{array}{l}1.11^{* *} \\
(1.00,1.23) \\
2.04\end{array}$ & - & & $\begin{array}{l}1.03 \\
(0.97,1.09) \\
0.91\end{array}$ & $\begin{array}{l}1.06^{* *} \\
(1.01,1.11) \\
2.47\end{array}$ \\
\hline $\begin{array}{l}\text { Intersection } \\
\text { vs. population } \\
\text { density }^{\mathrm{a}}\end{array}$ & $\begin{array}{l}0.93^{* *} \\
(0.87,0.99) \\
-2.17\end{array}$ & $\begin{array}{l}1.24^{* * *} \\
(1.12,1.38) \\
4.03\end{array}$ & $\begin{array}{l}1.23^{* * *} \\
(1.08,1.40) \\
3.06\end{array}$ & $\begin{array}{l}1.31^{* * *} \\
(1.12,1.53) \\
3.41\end{array}$ & $\begin{array}{l}0.99 \\
(0.87,1.13) \\
-0.12\end{array}$ & $\begin{array}{l}1.18^{* * *} \\
(1.06,1.32) \\
3.10\end{array}$ & $\begin{array}{l}1.04 \\
(0.96,1.13) \\
0.97\end{array}$ \\
\hline Home in CBD & $\begin{array}{l}0.37^{* * *} \\
(0.26,0.55) \\
-5.07\end{array}$ & & & $\begin{array}{l}0.33^{* * *} \\
(0.19,0.57) \\
-3.95\end{array}$ & & $\begin{array}{l}0.45^{* * *} \\
(0.33,0.63) \\
-4.79\end{array}$ & \\
\hline Land-use mix & $\begin{array}{l}1.06 \\
(0.84,1.34) \\
0.48\end{array}$ & $\begin{array}{l}0.83 \\
(0.61,1.13) \\
-1.21\end{array}$ & $\begin{array}{l}0.50^{* * *} \\
(0.34,0.72) \\
-3.69\end{array}$ & $\begin{array}{l}1.20 \\
(0.81,1.77) \\
0.89\end{array}$ & $\begin{array}{l}1.66^{* *} \\
(1.12,2.46 \\
2.50)\end{array}$ & $\begin{array}{l}1.06 \\
(0.74,1.53) \\
0.32\end{array}$ & $\begin{array}{l}1.09 \\
(0.86,1.38) \\
0.73\end{array}$ \\
\hline
\end{tabular}




\begin{tabular}{|c|c|c|c|c|c|c|}
\hline $\begin{array}{l}\text { Ln distance to } \\
\text { work/school }\end{array}$ & $\begin{array}{l}0.98 \\
(0.95,1.02) \\
-0.85\end{array}$ & $\begin{array}{l}0.87^{* * *} \\
(0.82,0.92) \\
-4.85\end{array}$ & $\begin{array}{l}0.84^{* * *} \\
(0.78,0.92) \\
-4.05\end{array}$ & - & $\begin{array}{l}0.92^{* * *} \\
(0.87,0.96) \\
-3.45\end{array}$ & $\begin{array}{l}0.88^{* * *} \\
(0.85,0.91) \\
-6.71\end{array}$ \\
\hline $\begin{array}{l}\text { Percent nonmo- } \\
\text { torized commut- } \\
\text { ers, home tract }\end{array}$ & \multicolumn{3}{|l|}{$\begin{array}{l}1.02^{* * *} \\
(1.01,1.03) \\
3.46 \\
\end{array}$} & $\begin{array}{l}1.02^{* * *} \\
(1.00,1.03) \\
2.82\end{array}$ & \multicolumn{2}{|l|}{$\begin{array}{l}1.02^{* * *} \\
(1.01,1.03) \\
5.14 \\
\end{array}$} \\
\hline Local job access & \multicolumn{3}{|l|}{-} & $\begin{array}{l}1.01 \\
(0.99,1.02) \\
1.13\end{array}$ & \multicolumn{2}{|l|}{$\begin{array}{l}1.01 \\
(1.00,1.02) \\
1.25 \\
\end{array}$} \\
\hline $\begin{array}{l}\text { Regional job } \\
\text { access }\end{array}$ & \multicolumn{3}{|l|}{-} & $\begin{array}{l}0.99^{* *} \\
(0.99,1.00) \\
-2.16\end{array}$ & \multicolumn{2}{|l|}{$\begin{array}{l}1.00^{*} \\
(0.99,1.00) \\
-1.66\end{array}$} \\
\hline $\begin{array}{l}\text { Proportion park, } \\
1 \text { mile from } \\
\text { home }\end{array}$ & \multicolumn{3}{|l|}{$\begin{array}{l}0.61^{* *} \\
(0.41,0.89) \\
-2.54\end{array}$} & $\begin{array}{l}1.00 \\
(0.54,1.83) \\
-0.01\end{array}$ & \multicolumn{2}{|l|}{$\begin{array}{l}0.87 \\
(0.59,1.28) \\
-0.72\end{array}$} \\
\hline $\begin{array}{l}\text { Bike route } \mathrm{km}, 1 \\
\text { mile from home } \\
(\text { tens of } \mathrm{km})\end{array}$ & \multicolumn{3}{|l|}{$\begin{array}{l}0.96 \\
(0.91,1.03) \\
-1.10 \\
\end{array}$} & $\begin{array}{l}1.04 \\
(0.97,1.11) \\
1.17 \\
\end{array}$ & \multicolumn{2}{|l|}{$\begin{array}{l}1.07^{* *} \\
(1.01,1.13) \\
2.45 \\
\end{array}$} \\
\hline $\begin{array}{l}\text { Bike route } \\
\text { available, } 75 \text { th } \\
\text { percentile home } \\
\text { and work/school }\end{array}$ & \multicolumn{3}{|l|}{$\begin{array}{l}1.25^{* * *} \\
(1.08,1.46) \\
2.94\end{array}$} & - & \multicolumn{2}{|l|}{$\begin{array}{l}1.04 \\
(0.92,1.17) \\
0.57\end{array}$} \\
\hline Household size & \multicolumn{3}{|l|}{$\begin{array}{l}1.00 \\
(0.96,1.03) \\
-0.29 \\
\end{array}$} & $\begin{array}{l}0.87^{* * *} \\
(0.82,0.92) \\
-4.91\end{array}$ & \multicolumn{2}{|l|}{$\begin{array}{l}0.91^{\text {*** }} \\
(0.87,0.94) \\
-4.64\end{array}$} \\
\hline $\begin{array}{l}\text { Children in } \\
\text { Household }\end{array}$ & \multicolumn{3}{|l|}{-} & $\begin{array}{l}0.83^{* *} \\
(0.71,0.97) \\
-2.40\end{array}$ & \multicolumn{2}{|l|}{$\begin{array}{l}0.79^{* * *} \\
(0.71,0.88) \\
-4.30\end{array}$} \\
\hline One car & \multicolumn{3}{|l|}{$\begin{array}{l}0.98 \\
(0.81,1.20) \\
-0.16 \\
\end{array}$} & $\begin{array}{l}0.52^{* * *} \\
(0.40,0.68) \\
-4.86\end{array}$ & \multicolumn{2}{|l|}{$\begin{array}{l}0.48^{* * *} \\
(0.38,0.59) \\
-6.57 \\
\end{array}$} \\
\hline Two cars & \multicolumn{3}{|l|}{$\begin{array}{l}0.94 \\
(0.76,1.15) \\
-0.60 \\
\end{array}$} & $\begin{array}{l}0.41^{\text {*** }} \\
(0.31,0.54) \\
-6.26\end{array}$ & \multicolumn{2}{|l|}{$\begin{array}{l}0.28^{* * *} \\
(0.22,0.36) \\
-10.76 \\
\end{array}$} \\
\hline $3+$ cars & \multicolumn{3}{|l|}{$\begin{array}{l}0.95 \\
(0.76,1.18) \\
-0.47\end{array}$} & $\begin{array}{l}0.34^{* * *} \\
(0.25,0.47) \\
-6.85\end{array}$ & \multicolumn{2}{|l|}{$\begin{array}{l}0.26^{* * *} \\
(0.20,0.33) \\
-10.79\end{array}$} \\
\hline Two bikes & \multicolumn{3}{|l|}{$\begin{array}{l}1.22^{* * *} \\
(1.08,1.38) \\
3.14\end{array}$} & $\begin{array}{l}1.54^{* * *} \\
(1.34,1.77) \\
6.00\end{array}$ & \multicolumn{2}{|l|}{$\begin{array}{l}1.56^{* * *} \\
(1.39,1.75) \\
7.53\end{array}$} \\
\hline $3+$ bikes & \multicolumn{3}{|c|}{$1.68^{* * *}(1.50,1.89) 8.76$} & $\begin{array}{l}3.02^{* * *} \\
(2.60,3.50) \\
14.62\end{array}$ & \multicolumn{2}{|c|}{$\begin{array}{l}3.40^{* * *} \\
(3.04,3.8021 .50\end{array}$} \\
\hline $\begin{array}{l}\text { Transit user in } \\
\text { Household }\end{array}$ & \multicolumn{3}{|l|}{$\begin{array}{l}1.10^{* *} \\
(1.01,1.21) \\
2.11\end{array}$} & $\begin{array}{l}1.13^{*} \\
(0.99,1.29) \\
1.83\end{array}$ & \multicolumn{2}{|l|}{$\begin{array}{l}1.28^{* * *} \\
(1.17,1.41) \\
5.17\end{array}$} \\
\hline
\end{tabular}




\begin{tabular}{|c|c|c|c|c|c|}
\hline $\begin{array}{l}\text { Income (tens of } \\
\text { thousands USD) }\end{array}$ & \multicolumn{3}{|l|}{$\begin{array}{l}0.94^{* * *} \\
(0.92,0.96) \\
-6.57\end{array}$} & $\begin{array}{l}(0.94,0.99) \\
0.97^{* *} \\
-2.49\end{array}$ & $\begin{array}{l}0.98^{* *} \\
(0.96,1.00) \\
-2.24\end{array}$ \\
\hline $\begin{array}{l}\text { Income squared } \\
\text { (millions USD- } \\
\text { squared) }\end{array}$ & \multicolumn{3}{|l|}{$\begin{array}{l}1.18^{* * *} \\
(1.11,1.26) \\
5.12\end{array}$} & $\begin{array}{l}1.08^{*} \\
(0.99,1.18) \\
1.81\end{array}$ & $\begin{array}{l}1.07^{* *} \\
(1.01,1.14) \\
2.16\end{array}$ \\
\hline Home owner & \multicolumn{3}{|l|}{$\begin{array}{l}0.96 \\
(0.87,1.06) \\
-0.83\end{array}$} & $\begin{array}{l}0.85^{* *} \\
(0.72,1.00) \\
-2.00\end{array}$ & $\begin{array}{l}0.93 \\
(0.82,1.06) \\
-1.09\end{array}$ \\
\hline Apartment & \multicolumn{3}{|l|}{$\begin{array}{l}0.87^{*} \\
(0.75,1.00) \\
-1.95\end{array}$} & $\begin{array}{l}0.89 \\
(0.72,1.11) \\
-1.02\end{array}$ & $\begin{array}{l}1.01 \\
(0.86,1.17) \\
0.07\end{array}$ \\
\hline Female & - & $\begin{array}{l}0.91 \\
(0.66,1.26) \\
-0.55\end{array}$ & $\begin{array}{l}0.91 \\
(0.61,1.36) \\
-0.44\end{array}$ & - & - \\
\hline Male & $\begin{array}{l}1.16^{* * *} \\
(1.08,1.25) \\
3.99\end{array}$ & $\begin{array}{l}1.52^{* * *} \\
(1.11,2.09) \\
2.61\end{array}$ & $\begin{array}{l}2.12^{* * *} \\
(1.44,3.11) \\
3.84\end{array}$ & $\begin{array}{l}2.09^{* * *} \\
(1.33,3.28) \\
3.20\end{array}$ & $\begin{array}{l}2.39^{* * *} \\
(1.66,3.47) \\
4.63\end{array}$ \\
\hline Driver's license & $\begin{array}{l}0.62^{* * *} \\
(0.52,0.76) \\
-4.81\end{array}$ & & & $\begin{array}{l}0.89 \\
(0.75,1.06 \\
-1.32)\end{array}$ & $\begin{array}{l}0.71^{* * *} \\
(0.58,0.87) \\
-3.23\end{array}$ \\
\hline $\begin{array}{l}\text { Scientist, } \\
\text { Teacher, Doctor }\end{array}$ & - & & & - & $\begin{array}{l}1.20^{* * *} \\
(1.09,1.31) \\
3.89\end{array}$ \\
\hline Ln age & - & & & $\begin{array}{l}0.50^{* * *} \\
(0.43,0.58) \\
-8.98\end{array}$ & $\begin{array}{l}0.58^{* * *} \\
(0.52,0.66-8.28\end{array}$ \\
\hline Disabled & $\begin{array}{l}0.59^{* * *} \\
(0.44,0.78) \\
-3.68\end{array}$ & & & $\begin{array}{l}0.54^{* * *} \\
(0.45,0.64) \\
-6.82\end{array}$ & $\begin{array}{l}0.62^{* *} \\
(0.43,0.91) \\
-2.43\end{array}$ \\
\hline $\begin{array}{l}\text { Transit pass } \\
\text { holder }\end{array}$ & - & & & $\begin{array}{l}1.14 \\
(0.94,1.38) \\
1.36\end{array}$ & $\begin{array}{l}1.30^{* * *} \\
(1.16,1.47) \\
4.34\end{array}$ \\
\hline $\begin{array}{l}\text { Walk Trips in } 7 \\
\text { Days }\end{array}$ & $\begin{array}{l}1.07^{* * *} \\
(1.06,1.08) \\
16.79\end{array}$ & & & $\begin{array}{l}1.06^{* * *} \\
(1.05,1.07) \\
12.22\end{array}$ & $\begin{array}{l}1.06^{\text {*** }} \\
(1.05,1.07 \\
14.15)\end{array}$ \\
\hline White & $\begin{array}{l}0.97 \\
(0.90,1.04) \\
-0.92\end{array}$ & & & $\begin{array}{l}1.00 \\
(0.89,1.13) \\
0.02\end{array}$ & $\begin{array}{l}1.05 \\
(0.96,1.14) \\
1.05\end{array}$ \\
\hline Bachelor degree & - & & & $\begin{array}{l}1.14^{* *} \\
(1.00,1.29) \\
2.03\end{array}$ & $\begin{array}{l}1.17^{* * *} \\
(1.07,1.28) \\
3.54\end{array}$ \\
\hline Spring & $\begin{array}{l}1.17^{* * *} \\
(1.04,1.31) \\
2.69\end{array}$ & & & $\begin{array}{l}1.17^{*} \\
(0.98,1.39) \\
1.77\end{array}$ & $\begin{array}{l}1.17^{* * *} \\
(1.05,1.31) \\
2.83\end{array}$ \\
\hline
\end{tabular}




\begin{tabular}{|l|l|l|l|}
\hline Summer & $1.39^{* * *}$ & $1.25^{* * *}$ & $1.40^{* * *}$ \\
& $(1.26,1.54)$ & $(1.08,1.45)$ & $(1.26,1.55)$ \\
& 6.44 & 2.99 & 6.42 \\
\hline \multirow{2}{*}{ Fall } & $1.15^{* * *}$ & $1.20^{* * *}$ & $1.36^{* * *}$ \\
& $(1.05,1.27)$ & $(1.05,1.38)$ & $(1.23,1.50)$ \\
& 2.90 & 2.62 & 6.04 \\
\hline Ln alpha $^{\mathrm{b}}$ & 0.57 & 1.73 & 1.40 \\
\hline
\end{tabular}

a These are variables created using principal component analysis.

${ }^{\mathrm{b}}$ Alpha is the dispersion parameter for negative binomial regression models. If alpha is zero (or $\ln$ alpha is negative infinity), the negative binomial model is equivalent to the Poisson model.

Table 7. Weighted average marginal effects on 7-day bicycling frequency Note: $95 \%$ confidence intervals are given below point estimates. Asterisks designate statistical significance, where ${ }^{* * *}$ indicates $\mathrm{p}<0.01,{ }^{* *}$ indicates $\mathrm{p}<0.05,{ }^{*}$ indicates $\mathrm{p}<0.10$. $\mathrm{z}$-statistics are shown in italics.

\begin{tabular}{|c|c|c|c|c|c|c|c|}
\hline \multirow[b]{2}{*}{ Variable } & \multicolumn{3}{|c|}{ Schoolchildren } & \multicolumn{2}{|c|}{ Not-Employed Adults } & \multicolumn{2}{|c|}{ Employed Adults } \\
\hline & Elementary & Middle & High & Female & Male & Female & Male \\
\hline General density ${ }^{a}$ & $\begin{array}{l}-0.17^{* * *} \\
(-0.24,- \\
0.10) \\
-4.76\end{array}$ & $\begin{array}{l}-0.15^{* * *} \\
(-0.23,- \\
0.07) \\
-3.56\end{array}$ & $\begin{array}{l}0.12^{* * *} \\
(0.04,0.20) \\
2.96\end{array}$ & $\begin{array}{l}0.01 \\
(-0.03 \\
0.04) \\
0.45\end{array}$ & $\begin{array}{l}0.11^{*} \\
(-0.01 \\
0.23) \\
1.82\end{array}$ & $\begin{array}{l}0.01 \\
(-0.02 \\
0.03) \\
0.49\end{array}$ & $\begin{array}{l}0.02 \\
(-0.02 \\
0.07) \\
1.04\end{array}$ \\
\hline $\begin{array}{l}\text { Home vs. work/ } \\
\text { school }^{a}\end{array}$ & $\begin{array}{l}0.04 \\
(-0.17 \\
0.25) \\
0.37 \\
\end{array}$ & $\begin{array}{l}0.09 \\
(-0.11,0.30) \\
0.88\end{array}$ & $\begin{array}{l}0.17^{* *} \\
(0.01,0.34) \\
2.02\end{array}$ & - & & $\begin{array}{l}0.02 \\
(-0.02 \\
0.05) \\
0.91 \\
\end{array}$ & $\begin{array}{l}0.07^{* *} \\
(0.01,0.12) \\
2.45\end{array}$ \\
\hline $\begin{array}{l}\text { Intersection } \\
\text { vs. population } \\
\text { density }^{\mathrm{a}}\end{array}$ & $\begin{array}{l}-0.20^{* *} \\
(-0.38 \\
-0.02) \\
-2.16 \\
\end{array}$ & $\begin{array}{l}0.44^{* * *} \\
(0.23,0.66) \\
4.02\end{array}$ & $\begin{array}{l}0.33^{* * *} \\
(0.11,0.54) \\
2.97\end{array}$ & $\begin{array}{l}0.13^{* * *} \\
(0.05,0.21) \\
3.37\end{array}$ & $\begin{array}{l}-0.01 \\
(-0.22 \\
0.20) \\
-0.12 \\
\end{array}$ & $\begin{array}{l}0.09^{* * *} \\
(0.03,0.15) \\
3.07\end{array}$ & $\begin{array}{l}0.05 \\
(-0.05 \\
0.14) \\
0.97 \\
\end{array}$ \\
\hline Home in CBD & \multicolumn{3}{|c|}{$\begin{array}{l}-2.13^{* * *} \\
(-2.96,-1.29) \\
-4.96\end{array}$} & \multicolumn{2}{|c|}{$\begin{array}{l}-1.04^{* * *} \\
(-1.58,-0.51) \\
-3.82\end{array}$} & \multicolumn{2}{|l|}{$\begin{array}{l}-0.69^{* * *} \\
(-0.98,-0.40) \\
-4.69\end{array}$} \\
\hline Land-use mix & $\begin{array}{l}0.15 \\
(-0.47 \\
0.78) \\
0.48 \\
\end{array}$ & $\begin{array}{l}-0.39 \\
(-1.02,0.24) \\
-1.21\end{array}$ & $\begin{array}{l}-1.12^{* * *} \\
(-1.73 \\
-0.52) \\
-3.63 \\
\end{array}$ & \begin{tabular}{|l|}
0.09 \\
$(-0.11$ \\
$0.28)$ \\
0.88 \\
\end{tabular} & $\begin{array}{l}0.82^{* *} \\
(0.17,1.46) \\
2.47\end{array}$ & $\begin{array}{l}0.03 \\
(-0.17 \\
0.23) \\
0.32 \\
\end{array}$ & $\begin{array}{l}0.10 \\
(-0.17 \\
0.38) \\
0.73 \\
\end{array}$ \\
\hline $\begin{array}{l}\text { Ln distance to } \\
\text { work/school }\end{array}$ & $\begin{array}{l}-0.04 \\
(-0.14 \\
0.06) \\
-0.85 \\
\end{array}$ & $\begin{array}{l}-0.29^{* * *} \\
(-0.41 \\
-0.17) \\
-4.70 \\
\end{array}$ & $\begin{array}{l}-0.27^{* * *} \\
(-0.41 \\
-0.14) \\
-3.94 \\
\end{array}$ & - & & $\begin{array}{l}-0.05^{* * *} \\
(-0.08 \\
-0.02) \\
-3.38\end{array}$ & $\begin{array}{l}-0.15^{* * *} \\
(-0.20 \\
-0.11) \\
-6.52 \\
\end{array}$ \\
\hline $\begin{array}{l}\text { Percent nonmo- } \\
\text { torized commut- } \\
\text { ers, home tract }\end{array}$ & \multicolumn{3}{|l|}{$\begin{array}{l}0.04^{* * *} \\
(0.02,0.06) \\
3.42\end{array}$} & \multicolumn{2}{|l|}{$\begin{array}{l}0.02^{* * *} \\
(0.00,0.03) \\
2.78 \\
\end{array}$} & \multicolumn{2}{|l|}{$\begin{array}{l}0.02^{* * *} \\
(0.01,0.02) \\
5.02\end{array}$} \\
\hline Local job access & \multicolumn{3}{|l|}{-} & \multicolumn{2}{|l|}{$\begin{array}{l}0.01 \\
(-0.01,0.02) \\
1.13\end{array}$} & \multicolumn{2}{|l|}{$\begin{array}{l}0.01 \\
(-0.00,0.02) \\
1.25\end{array}$} \\
\hline
\end{tabular}




\begin{tabular}{|c|c|c|c|}
\hline $\begin{array}{l}\text { Regional job } \\
\text { access }\end{array}$ & - & $\begin{array}{l}-0.01^{* *} \\
(-0.01,-0.00) \\
-2.15 \\
\end{array}$ & $\begin{array}{l}-0.00^{*} \\
(-0.01,0.00) \\
-1.66 \\
\end{array}$ \\
\hline $\begin{array}{l}\text { Proportion park, } \\
1 \text { mile from } \\
\text { home }\end{array}$ & $\begin{array}{l}-1.08^{* *} \\
(-1.91,-0.24) \\
-2.53\end{array}$ & $\begin{array}{l}-0.00 \\
(-0.58,0.57) \\
-0.01\end{array}$ & $\begin{array}{l}-0.12 \\
(-0.46,0.22) \\
-0.72\end{array}$ \\
\hline $\begin{array}{l}\text { Bike route } \mathrm{km}, 1 \\
\text { mile from home } \\
(\text { tens of } \mathrm{km})\end{array}$ & $\begin{array}{l}-0.08 \\
(-0.21,0.06) \\
-1.10 \\
\end{array}$ & $\begin{array}{l}0.04 \\
(-0.03,0.10) \\
1.17 \\
\end{array}$ & $\begin{array}{l}0.06^{* *} \\
(0.01,0.11) 2.45\end{array}$ \\
\hline $\begin{array}{l}\text { Bike route avail- } \\
\text { able, } 75 \text { th percen- } \\
\text { tile home and } \\
\text { work/school }\end{array}$ & $\begin{array}{l}0.49^{* * *} \\
(0.16,0.82) \\
2.94\end{array}$ & - & $\begin{array}{l}0.03 \\
(-0.08,0.14) \\
0.57\end{array}$ \\
\hline Household size & $\begin{array}{l}-0.01 \\
(-0.08,0.06) \\
-0.29 \\
\end{array}$ & $\begin{array}{l}-0.14^{* * *} \\
(-0.19,-0.08) \\
-4.88 \\
\end{array}$ & \begin{tabular}{|l|}
$-0.09^{* * *}$ \\
$(-0.12,-0.05)$ \\
-4.66 \\
\end{tabular} \\
\hline $\begin{array}{l}\text { Children in } \\
\text { household }\end{array}$ & - & $\begin{array}{l}-0.17^{* *} \\
(-0.31,-0.03) \\
-2.40 \\
\end{array}$ & $\begin{array}{l}-0.20^{* * *} \\
(-0.30,-0.11) \\
-4.24 \\
\end{array}$ \\
\hline One car & $\begin{array}{l}-0.04 \\
(-0.49,0.42) \\
-0.16 \\
\end{array}$ & $\begin{array}{l}-1.00^{* * *} \\
(-1.54,-0.47) \\
-3.69\end{array}$ & $\begin{array}{l}-1.36^{* * *} \\
(-1.91,-0.81) \\
-4.81 \\
\end{array}$ \\
\hline Two cars & $\begin{array}{l}-0.14 \\
(-0.60,0.33) \\
-0.58 \\
\end{array}$ & $\begin{array}{l}-1.23^{* * *} \\
(-1.78,-0.67) \\
-4.36 \\
\end{array}$ & $\begin{array}{l}-1.86^{* * *} \\
(-2.43,-1.29) \\
-6.41 \\
\end{array}$ \\
\hline $3+$ cars & $\begin{array}{l}-0.12 \\
(-0.61,0.38) \\
-0.46 \\
\end{array}$ & $\begin{array}{l}-1.36^{* * *} \\
(-1.93,-0.80) \\
-4.71 \\
\end{array}$ & $\begin{array}{l}-1.92^{* * *} \\
(-2.50,-1.34) \\
-6.53 \\
\end{array}$ \\
\hline Two bikes & $\begin{array}{l}0.33^{* * *} \\
(0.13,0.53) \\
3.22 \\
\end{array}$ & $\begin{array}{l}0.30^{* * *} \\
(0.20,0.41) \\
5.65 \\
\end{array}$ & $\begin{array}{l}0.25^{* * *} \\
(0.18,0.31) \\
7.41 \\
\end{array}$ \\
\hline $3+$ bikes & $\begin{array}{l}1.01^{* * *} \\
(0.81,1.22) \\
9.90\end{array}$ & $\begin{array}{l}1.13^{* * *} \\
(0.93,1.33) \\
10.90 \\
\end{array}$ & $\begin{array}{l}1.07^{* * *} \\
(0.96,1.18) \\
19.02 \\
\end{array}$ \\
\hline $\begin{array}{l}\text { Transit user in } \\
\text { household }\end{array}$ & $\begin{array}{l}0.22^{* *} \\
(0.01,0.43) \\
2.07\end{array}$ & $\begin{array}{l}0.12^{*} \\
(-0.01,0.24) \\
1.80 \\
\end{array}$ & $\begin{array}{l}0.23^{* * *} \\
(0.14,0.31) \\
4.96 \\
\end{array}$ \\
\hline $\begin{array}{l}\text { Income (tens of } \\
\text { thousands USD) }\end{array}$ & $\begin{array}{l}-0.07^{* * *} \\
(-0.10,-0.05) \\
-6.71 \\
\end{array}$ & $\begin{array}{l}-0.02^{* * *} \\
(-0.04,-0.01) \\
-2.61 \\
\end{array}$ & $\begin{array}{l}-0.01^{* *} \\
(-0.02,-0.00) \\
-2.00 \\
\end{array}$ \\
\hline Home owner & $\begin{array}{l}-0.09 \\
(-0.30,0.12) \\
-0.83 \\
\end{array}$ & $\begin{array}{l}-0.16^{*} \\
(-0.33,0.00) \\
-1.94 \\
\end{array}$ & $\begin{array}{l}-0.06 \\
(-0.17,0.05) \\
-1.08 \\
\end{array}$ \\
\hline Apartment & $\begin{array}{l}-0.29^{* *} \\
(-0.57,-0.01) \\
-2.06\end{array}$ & $\begin{array}{l}-0.10 \\
(-0.29,0.09) \\
-1.06\end{array}$ & $\begin{array}{l}0.00 \\
(-0.13,0.14) \\
0.07\end{array}$ \\
\hline
\end{tabular}




\begin{tabular}{|c|c|c|c|c|c|}
\hline Male & $\begin{array}{l}0.39^{* * *} \\
(0.20,0.58) \\
3.99\end{array}$ & $\begin{array}{l}1.00^{* * *} \\
(0.78,1.22) \\
9.03\end{array}$ & $\begin{array}{l}1.23^{* * *} \\
(1.01,1.46) \\
10.76\end{array}$ & - & - \\
\hline Driver's license & $\begin{array}{l}-0.82^{* * *} \\
(-1.10,-0.55) \\
-5.94\end{array}$ & & & $\begin{array}{l}-0.11 \\
(-0.29,0.06) \\
-1.29\end{array}$ & $\begin{array}{l}-0.34^{* * *} \\
(-0.58,-0.10) \\
-2.82 \\
\end{array}$ \\
\hline $\begin{array}{l}\text { Scientist, teacher, } \\
\text { doctor }\end{array}$ & - & & & - & $\begin{array}{l}0.17^{* * *} \\
(0.08,0.26) \\
3.67 \\
\end{array}$ \\
\hline Ln age & - & & & $\begin{array}{l}-0.66^{* * *} \\
(-0.82,-0.49) \\
-7.85\end{array}$ & $\begin{array}{l}-0.47^{* * *} \\
(-0.59,-0.35) \\
-7.71\end{array}$ \\
\hline Disabled & $\begin{array}{l}-0.89^{* * *} \\
(-1.26,-0.53) \\
-4.76\end{array}$ & & & $\begin{array}{l}-0.47^{* * *} \\
(-0.58,-0.35) \\
-8.05\end{array}$ & $\begin{array}{l}-0.33^{* * *} \\
(-0.55,-0.12) \\
-3.06\end{array}$ \\
\hline $\begin{array}{l}\text { Transit pass } \\
\text { holder }\end{array}$ & - & & & $\begin{array}{l}0.13 \\
(-0.07,0.32) \\
1.30\end{array}$ & $\begin{array}{l}0.25^{* * *} \\
(0.13,0.37) \\
4.00\end{array}$ \\
\hline $\begin{array}{l}\text { Walk Trips in } 7 \\
\text { Days }\end{array}$ & $\begin{array}{l}0.14^{* * *} \\
(0.12,0.17) \\
12.15\end{array}$ & & & $\begin{array}{l}0.06^{* * *} \\
(0.04,0.07) \\
7.99\end{array}$ & $\begin{array}{l}0.05^{* * *} \\
(0.04,0.06) \\
11.76 \\
\end{array}$ \\
\hline White & $\begin{array}{l}-0.08 \\
(-0.24,0.09) \\
-0.92\end{array}$ & & & $\begin{array}{l}0.00 \\
(-0.11,0.12) \\
0.02\end{array}$ & $\begin{array}{l}0.04 \\
(-0.03,0.12) \\
1.06 \\
\end{array}$ \\
\hline Bachelor degree & - & & & $\begin{array}{l}0.13^{*} \\
(-0.00,0.25) \\
1.95\end{array}$ & $\begin{array}{l}0.14^{* * *} \\
(0.06,0.22) \\
3.52 \\
\end{array}$ \\
\hline Spring & $\begin{array}{l}0.32^{* * *} \\
(0.08,0.55) \\
2.66\end{array}$ & & & $\begin{array}{l}0.14^{*} \\
(-0.02,0.29) \\
1.73\end{array}$ & $\begin{array}{l}0.12^{* * *} \\
(0.04,0.21) \\
2.78\end{array}$ \\
\hline Summer & $\begin{array}{l}0.73^{* * *} \\
(0.51,0.95) \\
6.43 \\
\end{array}$ & & & $\begin{array}{l}0.21^{* * *} \\
(0.07,0.34) \\
2.97 \\
\end{array}$ & $\begin{array}{l}0.28^{* * *} \\
(0.19,0.37) \\
6.20 \\
\end{array}$ \\
\hline Fall & $\begin{array}{l}0.28^{* * *} \\
(0.10,0.47) \\
2.95\end{array}$ & & & $\begin{array}{l}0.17^{* * *} \\
(0.04,0.29) \\
2.62\end{array}$ & $\begin{array}{l}0.26^{* * *} \\
(0.17,0.34) \\
5.88\end{array}$ \\
\hline
\end{tabular}

a These are variables created using principal component analysis.

\subsection{Built environment factors}

Our models include estimates of the relationship between bicycling frequency and density, with density represented by the principal components of intersection and population densities at home and at work/ school, as well as a binary variable indicating whether a person's home is in a central business district. In addition, we estimated the relationship between bicycling and five other built environment factors: 
access to jobs and services, green space near home, availability of bicycle infrastructure near home and work/school, extent of local mixed-use development, and percent of commuters using nonmotorized modes. Here we discuss our findings for each in turn.

\subsubsection{Density}

As described in section 4.1, we used principal component analysis to address the multicollinearity of the intersection and population density variables around home and work. This led to a "general density" component, a component for high home accessibility relative to work/school ("home vs. work/school"), and a component for high intersection density relative to population density ("intersection vs. population density").

The general density variable has a negative relationship with cycling for elementary and middle school children, and has a positive relationship for high school children. It is also positive and marginally statistically significant for not-employed males, and not significant for the other categories. This is consistent with our expectations; younger children (and their parents) are more likely to be concerned about safety and are thus likely to be most comfortable biking in lower density settings. Several prior studies of children found a similar deterrent effect of density (e.g., Larsen et al., 2009; Moran et al., 2016). Older children and adults are more likely to be biking for transportation, and thus bike more in areas with more activity.

The second component, density at home relative to work/school, is not significant for elementary and middle school children, but has a positive relationship with bicycling for high school children. It also has a significant positive sign for employed adult males. This makes sense, as most bike trips begin or end at home. Controlling for overall density at both home and work, higher density near home is associated with more bicycling.

Finally, the third component represents high intersection density relative to population density. It has a positive and significant relationship with cycling for employed and not-employed females, as well as middle and high school students. This makes sense; higher levels of intersection density given a particular population density indicates that there are likely more routes available. There may also be a safety benefit as traffic is spread out onto fewer, smaller streets-Ladrón de Guevara, Washington, and Oh (2014) found that higher levels of intersection density have lower levels of fatal crashes, but higher levels of injury crashes. This component has a negative and significant relationship with biking for young children, indicating that a lower level of street connectivity given a particular level of density increases cycling. This can be interpreted as young children cycling for recreation primarily within their neighborhoods, perhaps on safe, disconnected cul-de-sacs, and not needing access to destinations via a connected street network.

The final density-related variable we include is a binary indicator for central business districts (CBDs). This variable is derived from a cluster analysis of census tracts based on several built environment characteristics, including density, accessibility, bicycle and pedestrian friendliness, and housing mix, and is defined in Salon (2016). CBD tracts are extremely dense; most of those in California are located in downtown San Francisco. Including this variable allows us to identify some nonlinearity in the relationship between density and bicycling. Living in a CBD tract has a large negative relationship with biking, and is significant in all models. CBDs have many alternative transportation options other than cycling available, and cycling may not be practical due to safety concerns. 


\subsubsection{Access to jobs and services}

We include three variables in our models to represent access to jobs and services: distance to school or work, local job accessibility within five miles of home, and regional job accessibility in the range from five to fifty miles from home.

The first, relevant for both school children and employed adults, is the logarithm of the straight-line distance between each person's home and their school or work location. We use the logarithm because we expect that variation in distance affects bicycling more at shorter distances than at longer distances. In general, people with longer commutes bicycle less. There is some variation in this, however. Distance to school does not have a statistically significant relationship with elementary school children's bicycling. This is consistent with the fact that substantially fewer elementary school children in this sample bike to school (1.5\%), compared with older children (4-5\%). Distance to school, therefore, may be less relevant for elementary school children's bicycling frequency.

When commute distance is included in the analysis, our local job access variable becomes statistically insignificant for employed adults. A negative relationship between regional job access and bicycling for both employed and not-employed adults remains statistically significant, however. Our interpretation is that more jobs beyond 5 miles also represent more destinations beyond 5 miles, which reduces the likelihood of bicycling for transportation.

\subsubsection{Green space}

The proportion of the land area within one mile devoted to parks is included as a measurement of local green space in our regression model. It is negatively associated with bicycling frequency for children, and not significantly associated with bicycling for adults. Although this negative association is different from what others have found regarding the relationship between green space and bicycling, it is intuitive in some respects. Parks present substantial barriers by reducing street connectivity, lengthening trip distances and discouraging bicycling - especially for children who may be more sensitive to distance than adults.

\subsubsection{Bicycle infrastructure availability and prevalence of nonmotorized commuting}

We measure bicycle infrastructure in length of designated bicycle routes within one mile of each respondent's home and work/school. Included in the estimated models are two representations of this information: length of bicycle routes within one mile of home, and a binary indicator for individuals for whom bike route prevalence is in the 75th percentile within one mile of both home and work/school locations. As expected, where these variables are statistically significant, they have positive associations with bicycling.

Our models also include a measure of the extent to which nonmotorized transport is used for commuting in the home census tract of each survey respondent. This metric is likely correlated with the overall bike-friendliness of the infrastructure, which includes aspects beyond bicycle lanes such as

traffic levels, speeds, and the prevalence of other cyclists on the roads. For all respondent categories, it is positively associated with bicycling frequency.

\subsubsection{Land-use mix}

We included an entropy measure to represent the mix of residential and nonresidential development within a mile of each respondent's home. It is calculated as $-\sum_{k} p_{\mathrm{i}} \ln \left(p_{i}\right) / \ln (k)$, where $p_{i}$ is the proportion of each land use in the area, and $k$ indicates the number of land uses (in our case, two). Winters et al. 
(2010) use this measure as well. The metric varies between 0 and 1 , where higher values indicate more balance between the two types of development in the neighborhood. For elementary and middle school children, land-use mix had no relationship with bicycling frequency. For high school children, however, more mixed areas are associated with lower rates of bicycling, all else equal. Land-use mix did not affect bicycling of employed adults and not-employed women, but had a positive relationship with bicycling for not-employed men.

\subsection{Socioeconomic factors}

This analysis includes a wide variety of household and individual socioeconomic factors as controls. Household-level factors include household size, the presence of children, vehicle and bicycle ownership, income, a home ownership indicator, an apartment indicator, and whether a member of the household commutes by transit. Individual factors include gender, age, and the number of walking trips reported in the last 7 days, as well as whether the person holds a driver's license, self-identifies as disabled, holds a transit pass, holds a bachelor's degree, or is white. For employed adults, an indicator for individuals who identify as scientists, teachers, or doctors is also included. Most of these factors are statistically significant predictors of bicycling frequency, and most of the estimated relationships are as expected. We provide details below.

\subsubsection{Household-level factors}

Household size is negatively associated with bicycling for adults, but has no relationship with children's bicycling. The presence of children has an additional negative relationship with bicycling for both employed and not-employed adults; many in the latter group are stay-at-home parents. This is interesting because one might imagine the opposite relationship; since children bicycle more than adults, we might have predicted that in families with children, the adults bicycle more as well.

Increasing levels of household bicycle ownership have a positive and increasing relationship with bicycling in all models, but increasing levels of household car ownership have a negative relationship with bicycling only for adults. The fact that children's bicycling frequency is unrelated to household vehicle ownership suggests that rides in household vehicles do not substitute for children's bicycling. It may be that children bicycle mainly when the alternative mode is walking, a school bus, or not taking the trip at all. This finding is consistent with prior literature (e.g, Ewing et al., 2004; Moran et al., 2016), but has not been previously highlighted because individual prior studies have not analyzed both adult and child bicycling.

Household income has a more complex relationship with bicycling frequency. As income rises from low levels, bicycling frequency declines rapidly. At high incomes- between $\$ 170$ and $\$ 215 \mathrm{~K}$ annually, according to our model estimates - this relationship becomes less important and may actually reverse. Our models represent this by including household income as both a linear and squared term.

\subsubsection{Individual-level factors}

Age and gender are included in our models as separate variables, and they are also interacted with other variables of interest. Age category is the key interaction variable in our children's bicycling analysis, and the key interaction variable is gender in our adult analysis. Table 8 reports comprehensive marginal effects for children's age category and adult gender. These marginal effects include not only the effect of the male and age category dummy variables, but also the effects of these variables embedded in the estimated effects of all of their interactions included in the model. 
Adult results regarding both age (older adults bike less; see Tables 6 and 7) and gender (women bike less; see Table 8) are consistent with expectations. Our results indicate that the gender difference is larger for not-employed adults than for employed adults, at approximately one bike trip each week. The gender gap in cycling - males cycle more, on average, than females - is well documented in the literature (e.g., Pucher, Buehler, Merom, \& Bauman, 2011).

Among schoolchildren, we find that bicycling declines with age such that the average high schooler makes 0.59 fewer bicycle trips each week than the average elementary school child. Our model also estimates separate associations between gender and bicycling for elementary, middle, and high school students. The estimated marginal effects of being a boy, given that one is in a particular age group, get larger as children get older (see Table 7). For elementary age children, boys are predicted to make 0.39 more weekly bike trips than girls, holding all else constant. For middle and high school age children, that gender difference is 1.00 and 1.23 , respectively.

Table 8. Comprehensive weighted average marginal effects for key interaction variables

\begin{tabular}{|l|l|l|l|}
\hline & Children & Not-Employed Adults & Employed Adults \\
\hline Elementary & Base & & \\
\cline { 1 - 2 } Middle & $-0.29^{* * *}$ & & \\
& $(-0.44,-0.13)$ & & \\
& -3.56 & & \multicolumn{2}{|l|}{} \\
\cline { 1 - 2 } High & $-0.59^{* * *}$ & & \multicolumn{2}{|l}{} \\
& $(-0.81,-0.38)$ & & base \\
\hline Woman & -5.46 & base & $0.68^{* * *}$ \\
\hline Man & & $0.95^{* * *}$ & $(0.61,0.75)$ \\
& & $(0.82,1.08)$ & 19.83 \\
\hline
\end{tabular}

Note: $95 \%$ confidence intervals and z-statistics are given below point estimates. Asterisks designate statistical significance, where ${ }^{* * *}$ indicates $\mathrm{p}<0.01,{ }^{* *}$ indicates $\mathrm{p}<0.05,{ }^{*}$ indicates $\mathrm{p}<0.10$.

As expected, individuals who self-identify as disabled bicycle less. Children and employed adults with driver's licenses bicycle less than those without licenses, and this relationship is especially large for children. Education plays a role as well, with adults holding bachelor's degrees bicycling more than lesseducated adults. Further, employed adults who self-identified as scientists, teachers, or doctors bicycle even more. Race, however, is not associated with bicycling in our model.

Of interest, we find that both walking and transit use are positively associated with bicycling frequency; individuals who take more walking trips also take more bicycling trips, and employed adults who hold transit passes do the same. This provides evidence that "alternative modes" (to the car) complement one another to provide a multimodal mobility package.

\subsection{Limitations}

Three limitations of this work bear mention. First, our models do not control for residential self-selection - the idea that some people choose where they live partly based on preferences for transportation, including bicycling. This does not mean that our relationship results are invalid; it means that the associations we find do not necessarily imply that changing the built environment will affect bicycling for individuals already living in a neighborhood. 
Second, there remains a substantial amount of variation in bicycling frequency that is not explained by our models. The deviance-based $\mathrm{R}^{2}$ (Cameron $\&$ Windmeijer, 1997; Brilleman, 2011) of the models ranges between 0.16 and 0.19 . Some of this variation undoubtedly reflects the random nature of individual-level weekly bicycling frequency, but some of it is also due to lack of data on all of the relevant determinants of bicycling.

Previous literature suggests some possible omitted variables. Attitudes toward biking have been shown to be predictive of bicycle travel (Willis et al., 2015). Other possible predictors include safety, both from traffic and, for children, from strangers (Buliung et al., 2014), and risk of bicycle theft (van Lierop, Grimsrud, \& El-Geneidy, 2015).

While omitting these potential predictors likely reduces the fit of the models, the larger concern is that they may be correlated with the covariates that are included in the model, causing omitted variable bias. In our model, for example, risk of bicycle theft may be correlated with residential location in the $\mathrm{CBD}$, resulting in the $\mathrm{CBD}$ coefficient in our model being more negative than it otherwise would be.

Finally, our data is entirely self-reported, and relies on the accuracy of the respondent's recall over the past seven days. Previous work has shown that GPS-prompted travel diaries have fewer people reporting zero trips than in self-report travel diaries (Salon, 2016). It is also possible that some people might not see recreational cycling as a "trip" (particularly for short trips made by children within the neighborhood). However, the question of how many trips were made has lower respondent burden than asking the details of each trip, and the respondent is primed to think of cycling which may help them recall shorter, recreational trips. We thus suspect that these data do not have the same underreporting problem that plagues travel diary data - especially for studies of active travel.

\section{Discussion and conclusion}

This study contributes to the existing literature with a focus on comparing the relationship between built environment characteristics and bicycling frequency across demographic groups. Some of our findings are consistent across our groups of focus - children and adults, men and women, and different children's age groups. Distance to work/school is negatively associated with bicycling, living in a central business district is negatively associated with bicycling, and living in a census tract where it is more common to commute by nonmotorized modes is positively associated with bicycling.

Others of our findings are markedly different for different demographics. Where statistically significant for adults and older children, density is positively associated with bicycling. For younger school children, however, our measure of general density near home and school has a statistically insignificant or even negative relationship with bicycling. Similarly, land-use mix has a positive relationship with bicycling for adults, but a negative relationship with bicycling for children.

These results might seem surprising at first, but they are actually quite intuitive. The hypothesized relationships are not clear between density and bicycling. There could be a positive impact due to increased access to destinations in a dense area, or due to increased street network connectivity leading to more direct routes. There could also be a negative impact due to safety concerns; dense areas have more traffic, and this may suppress biking. High intersection counts could increase safety (because traffic is spread over many streets) or decrease it (because there are more intersections to cross, and many crashes occur at intersections).

Younger children and their parents are more likely to be concerned about safety and are thus likely to be more comfortable biking in lower density settings. Older children and adults are more likely to be biking for transportation, and thus are enticed by areas with more activity. Similarly, women may be more risk averse than men. 
We also find that children - and to some extent women - are especially sensitive to physical barriers and bicycle-friendly infrastructure. Plentiful bicycle infrastructure in both the home and school neighborhoods is strongly and positively associated with bicycling for children. Older children and women bike more in neighborhoods with high intersections per capita. Children also tend to bike much less in neighborhoods that have a high percent of park land within 1 mile of the home. Children are inclined to bike because it is fun and they cannot drive, but they can be deterred by safety concerns or lack of connected, plentiful infrastructure.

A key conclusion from this work, therefore, is that the relationship between bicycling and some built environment characteristics varies between types of people - most dramatically between adults and children. This finding complements the related literature that highlights heterogeneity among bicyclists by identifying bicyclist typologies (e.g., Damant-Sirois \& El-Geneidy, 2015; Dill \& McNeil, 2013).

To develop targeted policies with scarce resources, local policymakers need specific guidance as to which investments and policy changes will be most effective for creating "bikeable" neighborhoods. Our work indicates that the answer depends - at least in part - on who these bikeable neighborhoods are meant to serve. Bikeability for young children strongly emphasizes safety, connectivity, and low-traffic environments, while bikeability for adults emphasizes the attractiveness and number of destinations within biking distance. Putting bicycle lanes on arterial streets, therefore, serves only a portion of the bicycling public. These two goals need not compete with one other, however; it is a rare bicyclist who will complain of infrastructure that is too safe.

Building neighborhoods that are bikeable for children is likely to have a knock-on effect on bicycling for adults - both now and in the future. Many adult trips are made with children in tow, meaning that these trips cannot be made by bicycle if the available infrastructure is not bikeable for children. Because they cannot drive, children are more likely to bicycle than adults. Further, children who bike are more likely to become adults who bike (Thigpen, 2017). Creating neighborhoods that are bikeable for children, therefore, will help to create a society in which children and adults alike will consider bicycling a viable mode of transport.

\section{Acknowledgements}

Data collection and assembly for this project was funded by the California Department of Transportation (Contract No. 65A0404). The authors would also like to thank Susan Handy, who was the principal investigator on the original project and provided useful comments on an earlier draft of this manuscript. The contents of this report reflect the views of the authors who are responsible for the facts and accuracy of the data presented herein. The contents do not necessarily reflect the official views or policies of the State of California or the Federal Highway Administration. The authors also gratefully acknowledge partial support from the Center for Teaching Old Models New Tricks (TOMNET), a University Transportation Center sponsored by the US Department of Transportation through Grant No. 69A3551747116. 


\section{References}

Beenackers, M. A., Foster, S., Kamphuis, C. B. M., Titze, S., Divitini, M., Knuiman, M., van Lenthe, F., \& Giles-Corti, B. (2012). Taking up cycling after residential relocation: Built environment factors. American Journal of Preventive Medicine, 42(6), 610-615. doi: 10.1016/j.amepre.2012.02.021

Brilleman, S. (2011). DEVR2: Stata module to compute Cameron and Windmeijer's deviance based R-squared measure, Statistical Software Components S457340, Boston College Department of Economics, revised Oct. 15, 2011. Retrieved from https://ideas.repec.org/c/boc/bocode/s457340.html

Buehler, T., \& Handy, S. L. (2008). Fifty years of bicycle policy in Davis, California. Transportation Research Record: Journal of the Transportation Research Board, 2074, 52-57. doi:10.3141/2074-07

Buliung, R. N., Larsen, K., Hess, P., Faulkner, G., Fusco, C., \& Rothman, L. (2014). Driven to school: Social fears and traffic environments. In A. Walks (Ed), The urban political economy and ecology of automobility: Driving cities, driving inequality, driving politics (pp. 81-100). London: Routledge. doi:10.4324/9781315766188

California Department of Transportation. (2012). 2010-2012 California Household Transportation Survey (CHTS). Retrieved from https://catalog.data.gov/dataset/california-household-transportation-survey

Calthorpe Associates. (2012). Urban footprint technical summary. Retrieved from http://www.calthorpe.com/files/UrbanFootprint\%20Technical\%20Summary\%20-\%20July\%202012.pdf

Cameron, A. C., \& Windmeijer, F. A. (1997). An R-squared measure of goodness of fit for some common nonlinear regression models. Journal of Econometrics, 77(2), 329-342. doi:10.1016/S03044076(96)01818-0

Carlson, J. A., Saelens, B. E., Kerr, J., Schipperijn, J., Conway, T. L., Frank, L. D., ... \& Sallis, J. F. (2015). Association between neighborhood walkability and GPS-measured walking, bicycling and vehicle time in adolescents. Health \& Place, 32, 1-7. doi:10.1016/j.healthplace.2014.12.008

Cervero, R., \& Duncan, M. (2003). Walking, bicycling, and urban landscapes: Evidence from the San Francisco Bay Area. American Journal of Public Health, 93(9), 1478-1483. doi:10.2105/ AJPH.93.9.1478

Cervero, R., Sarmiento, O. L., Jacoby, E., Gomez, L. F., \& Neiman, A. (2009). Influences of built environments on walking and cycling: Lessons from Bogotá. International Journal of Sustainable Transportation, 3, 203-226. doi:10.1080/15568310802178314

Conrow, L. (2018). Factors that influence bicycling activity density in Sydney using varied crowdsourced activity datasets. In Understanding mobility and active transportation in urban areas through crowdsourced movement data (Doctoral dissertation). Arizona State University, Tempe, AZ. Retrieved from https://repository.asu.edu/items/49204

Cui, Y., Mishra, S., \& Welch, T. F. (2014). Land use effects on bicycle ridership: A framework for state planning agencies. Journal of Transport Geography, 41, 220-228. doi:10.1016/j.jtrangeo.2014.10.004

Damant-Sirois, G., \& El-Geneidy, A. M. (2015). Who cycles more? Determining cycling frequency through a segmentation approach in Montreal, Canada. Transportation Research Part A: Policy and Practice, 77, 113-125. doi:10.1016/j.tra.2015.03.028.

De Meester, F., Van Dyck, D., De Bourdeaudhuij, I., Deforche, B., Sallis, J. F., \& Cardon, G. (2012). Active living neighborhoods: Is neighborhood walkability a key element for Belgian adolescents? BMC Public Health, 12(7). doi:10.1186/1471-2458-12-7

Dill, J., \& Carr, T. (2003). Bicycle commuting and facilities in major U.S. cities: If you build them, commuters will use them. Transportation Research Record: Journal of the Transportation Research Board, 1828, 116-123. doi:10.3141/1828-14 
Dill, J., \& McNeil, N. (2013). Four types of cyclists? Examination of typology for better understanding of bicycling behavior and potential. Transportation Research Record: Journal of the Transportation Research Board, 2387, 129-138. doi:10.3141/2387-15

Ducheyne, F., De Bourdeaudhuij, I., Lenoir, M., Spittaels, H., \& Cardon, G. (2013). Children’s cycling skills: Development of a test and determination of individual and environmental correlates. Accident Analysis \& Prevention, 50, 688-697. doi:10.1016/j.aap.2012.06.021

Ewing, R., Schroeer, W., \& Greene, W. (2004). School location and student travel: Analysis of factors affecting mode choice. Transportation Research Record: Journal of the Transportation Research Board, 1895, 55-63. doi: 10.3141/1895-08

Fitch, D. T., Thigpen, C. G., \& Handy, S. L. (2016). Traffic stress and bicycling to elementary and junior high school: Evidence from Davis, California. Journal of Transport and Health, 3(4), 457-466. doi:10.1016/j.jth.2016.01.007

Frank, L. D., Bradley, M., Kavage, S., Chapman, J., \& Lawton, T. K. (2008). Urban form, travel time, and cost relationships with tour complexity and mode choice. Transportation, 35, 37-54. doi:10.1007/s11116-007-9136-6

Furth, P. G. (2012). Bicycling infrastructure for mass cycling. In J. Pucher \& R. Buehler (Eds.), City cycling (pp. 105-139). Cambridge, MA: MIT Press.

Garrard, J., Handy, S. L., \& Dill, J. (2012). Women and cycling. In J. Pucher \& R. Buehler (Eds.), City cycling (pp. 211-234). Cambridge, MA: MIT Press.

Handy S. L., Boarnet, M. G., Ewing, R., \& Killingsworth, R. E. (2002). How the built environment affects physical activity. Views from urban planning. American Journal of Preventive Medicine, 23(2S), 64-73. doi:10.1016/S0749-3797(02)00475-0

Handy, S. L., Xing, Y., \& Buehler, T. J. (2010). Factors associated with bicycle ownership and use: A study of six small U.S. cities. Transportation, 37(6), 967-985. doi:10.1007/s11116-010-9269-x

Krizek, K. J., \& Johnson, P. J. (2006). Proximity to trails and retail: Effects on urban cycling and walking. Journal of the American Planning Association, 72(1), 33-42. doi:10.1080/01944360608976722

Ladrón de Guevara, F., Washington, S., \& Oh, J. (2004). Forecasting crashes at the planning level: Simultaneous negative binomial crash model applied in Tucson, Arizona. Transportation Research Record: Journal of the Transportation Research Board, 1897, 191-99. doi:10.3141/1897-25

Larsen, K., Gilliland, J., Hess, P., Tucker, P., Irwin, J., \& He, M. (2009). The influence of the physical environment and sociodemographic characteristics on children's mode of travel to and from school. American Journal of Public Health, 99(3), 520-526. doi: 10.2105/AJPH.2008.135319

Ma, L. \& Dill, J. (2015). Association between the objective and perceived built environment and bicycling for transportation. Journal of Transport and Health, 2, 248-255. doi:10.1016/j.jth.2015.03.002

Mitra, R., \& Nash, S. (2018). Can the built environment explain gender gap in cycling? An exploration of university students' travel behavior in Toronto, Canada. International Journal of Sustainable Transportation. doi:10.1080/15568318.2018.1449919

Moran, M. R., Plaut, P., \& Baron-Epel, O. (2016). Do children walk where they bike? Exploring built environment correlates of children's walking and bicycling. Journal of Transport and Land Use, 9(2), 1-23. doi: $10.5198 /$ jtlu.2015.556

Moudon, A. V., Lee, C., Cheadle, A. D., Collier, C. W., Johnson, D., Schmid, T. L., \& Weather, R. D. (2005). Cycling and the built environment, a US perspective. Transportation Research Part D, 10, 245-261. doi: 10.1016/j.trd.2005.04.001

Parkin, J., Wardman, M., \& Page, M. (2007). Estimation of the determinants of bicycle mode share for the journey to work using census data. Transportation, 35(1), 93-109. doi:10.1007/s11116-007$9137-5$ 
Pikora ,T., Giles-Corti, B., Bull, F., Jamrozik, K., \& Donovan, R. (2003). Developing a framework for assessment of the environmental determinants of walking and cycling. Social Science \& Medicine, 56, 1673-1703. doi:10.1016/S0277-9536(02)00163-6

Pucher, J., \& Buehler, R. (2008). Making cycling irresistible: Lessons from the Netherlands, Denmark and Germany. Transport Reviews, 28(4), 495-528. doi:10.1080/01441640701806612

Pucher, J., Buehler, R., Merom, D., \& Bauman, A. (2011). Walking and cycling in the United States, 2001-2009: Evidence from the national household travel surveys. American Journal of Public Health, 101(S1): S310-17. doi:10.2105/AJPH.2010.300067

Pucher, J., Dill, J., \& Handy, S. (2010). Infrastructure, programs, and policies to increase bicycling: An international review. Preventive Medicine, 50, S106-S125. doi:10.1016/j.ypmed.2009.07.028

Rosenberg, D., Ding, D., Sallis, J. F., Kerr, J., Norman, G. J., Durant, N., ... Saelens, B. E. (2009). Neighborhood environment walkability scale for youth (NEWS-Y): Reliability and relationship with physical activity. Preventive Medicine, 49, 213-218. doi:10.1016/j.ypmed.2009.07.011

Salon, D. (2016). Estimating pedestrian and cyclist activity at the neighborhood scale. Journal of Transport Geography, 55, 11-21. doi:10.1016/j.jtrangeo.2016.06.023

Solon, G., Haider, S. J., \& Wooldridge, J. M. (2015). What are we weighting for? Journal of Human Resources, 50(2), 301-316. doi:10.3368/jhr.50.2.301

Thigpen, C. G. (2017). The reciprocal relationship between children and young adults' travel behavior and their travel attitudes, skills, and norms (doctoral dissertation). Retrieved from https://ncst.ucdavis.edu/ wp-content/uploads/2016/11/Thigpen_Thesis_Full_FINAL.pdf

Titze, S., Stronegger, W. J., Janschitz, S., \& Oja, P. (2008). Association of built-environment, socialenvironment and personal factors with bicycling as a mode of transportation among Austrian city dwellers. American Journal of Preventive Medicine, 47, 252-259. doi: 10.1016/j.ypmed.2008.02.019

Trapp, G., Giles-Corti, B., Christian, H., Bulsara, M., Timperio, A., McCormack, G., \& Villaneuva, K. (2011). On your bike! A cross-sectional study of the individual, social and environmental correlates of cycling to school. International Journal of Behavioral Nutrition and Physical Activity, 8(1), 1-10. doi:10.1186/1479-5868-8-123

U.S. Census Bureau. (2014). American Community Survey 5-year estimates. Retrieved from http:// www.census.gov

U.S. Census Bureau. (2010). LEHD Origin-destination employment statistics (LODES) data. Retrieved from http://lehd.ces.census.gov/data/

Van Dyck, D., Cardon, G., Deforche, B., \& De Bourdeaudhuij, I. (2009a). Lower neighborhood walkability and longer distance to school are related to physical activity in Belgian adolescents. Preventive Medicine, 48(6), 516-518. doi:10.1016/j.ypmed.2009.03.005

Van Dyck, D., Deforche, B., Cardon, G., \& De Bourdeaudhuij, I. (2009b). Neighborhood walkability and its particular importance for adults with a preference for passive transport. Health \& Place, 15(2), 496-504. doi:10.1016/j.healthplace.2008.08.010

Van Lierop, D., Grismsrud, M., \& El-Geneidy, A. (2015). Breaking into bicycle theft: Insights from Montreal, Canada. International Journal of Sustainable Transportation, 9(7), 490-501. doi:10.1080/ 15568318.2013.811332

Washington, S., Karlaftis, M., \& Mannering, F. (2011). Statistical and econometric methods for transportation data analysis, 2nd ed. Boca Raton, FL: CRC Press.

Wendel-Vos, G. C. W., Schuit, A. J., de Niet, R., Boshuizen, H. C., Saris, W. H. M., \& Kromhout, D. (2004). Factors of the physical environment associated with walking and bicycling. Medicine and Science in Sports and Exercise, 36(4), 725-730. doi:10.1249/01.MSS.0000121955.03461.0A 
Willis, D. P., Manaugh, K., \& El-Geneidy, A. (2015). Cycling under influence: Summarizing the influence of perceptions, attitudes, habits, and social environments on cycling for transportation. International Journal of Sustainable Transportation, 9(8), 565-579. doi:10.1080/15568318.2013.827285

Winters, M., Brauer, M., Setton, E. M., \& Teschke, K. (2010). Built environment influences on healthy transportation choices: Bicycling versus driving. Journal of Urban Health: Bulletin of the New York Academy of Medicine, 87(6), 969-993. doi:10.1007/s11524-010-9509-6

Wong, B., Faulkner, G., \& Buliung, R. (2011). GIS measured environmental correlates of active school transport: A systematic review of 14 studies. International Journal of Behavioral Nutrition and Physical Activity, 8(1), 1-22. doi:10.1186/1479-5868-8-39

Zhao, P. (2014). The impact of the built environment on bicycle commuting: Evidence from Beijing. Urban Studies, 51(5), 1019-1037. doi:10.1177/0042098013494423

\section{Appendix}

Appendix available as a supplemental file at www.jtlu.org/index.php/jtlu/article/view/1350. Supplementary files are located under "Article Tools" on the lower right side of the web page. 